1

2

\title{
Spread of endemic SARS-CoV-2 lineages in Russia
}

\author{
Galya V. Klink', Ksenia R. Safina², Sofya K. Garushyants', Mikhail Moldovan², Elena Nabieva², \\ The CoRGI (Coronavirus Russian Genetic Initiative) Consortium5, Andrey B. Komissarov³, \\ Dmitry Lioznov ${ }^{3.4}$, Georgii A Bazykin",*
}

\section{A.A. Kharkevich Institute for Information Transmission Problems of the Russian Academy of Sciences, Russia}

\section{${ }^{2}$ Skolkovo Institute of Science and Technology (Skoltech), Russia}

${ }_{3}^{3}$ Smorodintsev Research Institute of Influenza, Saint Petersburg, Russia

${ }^{4}$ First Pavlov State Medical University, Saint Petersburg, Russia.

${ }^{5}$ https://corgi.center/en/ (see the list of consortium members in Supplementary File 1)

\section{*Email: g.bazykin@skoltech.ru}

In 2021, the COVID-19 pandemic is characterized by global spread of several lineages with evidence for increased transmissibility. Russia is among the countries with the highest number of confirmed COVID-19 cases, making it a potential hotspot for emergence of novel variants. Here, we show that among the globally significant variants of concern, B.1.1.7 (501Y.V1), B.1.351 (501Y.V2) or P.1 (501Y.V3), none have been sampled in Russia before January 2021. Instead, since summer 2020, the epidemic in Russia has been characterized by the spread of two lineages that are rare elsewhere: B.1.1.317 and a sublineage of B.1.1 including B.1.1.397 (hereafter, B.1.1.397+). In February-March 2021, these lineages reached frequencies of $26.9 \%$ (95\% C.I.: $23.1 \%$ $31.1 \%)$ and $32.8 \%(95 \%$ C.I.28.6\%-37.2\%) respectively in Russia. Their frequency has increased in different parts of Russia. Together with the fact that these lineages carry several spike mutations of interest, this suggests that B.1.1.317 and B.1.1.397+ may be more transmissible than the previously predominant B.1.1, although there is no direct data on change in transmissibility. Comparison of frequency dynamics of lineages carrying subsets of characteristic mutations of B.1.1.317 and B.1.1.397+ suggests that, if indeed some of these mutations affect transmissibility, the transmission advantage of B.1.1.317 may be conferred by the (S:D138Y+S:S477N+S:A845S) combination; while the advantage of B.1.1.397+ may be conferred by the S:M153T change. On top of these lineages, in January 2021, B.1.1.7 emerged in Russia, reaching the frequency of $17.4 \%$ (95\% C.I.: 12.0\%-24.4\%) in March 2021. Additionally, we identify three novel distinct lineages, AT.1, and two lineages prospectively named B.1.1.v1 and B.1.1.v2, that have started to spread, together reaching the frequency of $11.8 \%(95 \%$ C.I.: $7.5 \%-18.1 \%)$ in March 2021. These lineages carry combinations of several notable mutations, including the S:E484K mutation of concern, deletions at a recurrent deletion region of the spike glycoprotein (S: $\Delta 140-142, S: \Delta 144$ or S: $\Delta 136-144$ ), and nsp6: $\Delta 106-108$ (also known as ORF1a: $\Delta 3675-3677)$. Community-based PCR testing indicates that these variants have continued to spread in April 2021, with the frequency of B.1.1.7 reaching 21.7\% (95\% C.I.: $12.3 \%-35.6 \%)$, and the joint frequency of B.1.1.v1 and B.1.1.v2, $15.2 \%$ (95\% C.I.: $7.6 \%-$ 28.2\%). The combinations of mutations observed in B.1.1.317, B.1.1.397+, AT.1, B.1.1.v1 and B.1.1.v2 together with frequency increase of these lineages make them candidate NoVariantspoft interesst.research that has not been certified by peer review and should not be used to guide clinical practice. 
medRxiv preprint doi: https://doi.org/10.1101/2021.05.25.21257695; this version posted May 27, 2021. The copyright holder for this preprint (which was not certified by peer review) is the author/funder, who has granted medRxiv a license to display the preprint in perpetuity.

It is made available under a CC-BY-NC-ND 4.0 International license .

\section{Introduction}

Continuing evolution of SARS-CoV-2 in humans leads to emergence of new variants with novel epidemiological and/or antigenic properties. In spring 2020, the S:D614G change has spread globally due to its fitness advantage ${ }_{12}^{12}$. Subsequently, a number of variants of concern, including B.1.1.7 (501Y.V1) first sampled in Great Britain in September, B.1.351 (501Y.V2) first sampled in South Africa in October, and P.1 (501Y.V3) first sampled in Brazil in December, were shown to be associated with increased transmissibility 3.5 . These variants are characterized by overlapping sets of changes in spike receptor-binding domain which affect ACE2 binding and antibody recognition, as well as other changes with demonstrated functional and antigenic effects. Emergence of SARS-CoV-2 variants with evidence for change in transmissibility, and possibly other properties, highlights the importance of continued surveillance of novel variants. In particular, locally arising variants that grow in frequency over time may suggest a transmission advantage, although such an increase may also occur by chance ${ }^{\circ}$.

Here, we show that the outbreak in Russia is characterized by a spread of two lineages, B.1.1.317 and B.1.1.397+, which are highly prevalent in Russia but rarely appear in nonRussian samples. We trace the accumulation of sequential mutations in the evolution of these lineages, and single out the spike mutations that are followed by a burst in frequency. If the frequency increase of B.1.1.317 and B.1.1.397+ has been indeed driven by changes in the intrinsic properties of the virus rather than by epidemiology, it is these mutations in spike that most likely have led to this increase, although importantly we lack direct transmission data to verify causality. We also describe three novel candidate variants of interest that are characterized by a rapid increase in frequency and combinations of important spike mutations, including the E484K mutation of concern.

\section{Results}

\section{High-frequency variants in Russia}

We analyzed 4,487 SARS-CoV-2 sequences with known sampling dates obtained in Russia between February 25, 2020 - March 28, 2021. 2,842 of these samples are deposited to GISAID , while the remaining 1,645 (all dating to February-November 2020) will be made available through another repository. All 968 analyzed samples from December 2020 - March 2021 are available on GISAID. The vast majority of samples over this period came from several genomic surveillance programs which were not targeted towards particular variants, although representation of Russia's regions varied with time.

Throughout the pandemic, the SARS-CoV-2 diversity in Russia has been predominated by the B.1.1 Pango lineage which is frequent in Europe, as well as lineages descendant from it (Fig. 1). Three B.1.1-derived lineages with the higher prevalence in Russia in the beginning of 2021 were B.1.1.7, which was firstly introduced in Russia at the end of 2020, as well as two other lineages, B.1.1.317 and B.1.1.397, that appeared in Russia and July, 2020, respectively. B.1.1.317 was first sampled in Vietnam on March 27, 2020; within Russia, it was first sampled on April 5, 2020 in Moscow, spreading across the country throughout 2020 (Fig. 2). B.1.1.397 was first sampled in the Krasnoyarsk Region of Russia on July 22, 2020. By summer 2020, both B.1.1.317 and B.1.1.397 were frequent throughout Russia (Fig. 2). 
medRxiv preprint doi: https://doi.org/10.1101/2021.05.25.21257695; this version posted May 27, 2021. The copyright holder for this preprint (which was not certified by peer review) is the author/funder, who has granted medRxiv a license to display the preprint in perpetuity.

It is made available under a CC-BY-NC-ND 4.0 International license .
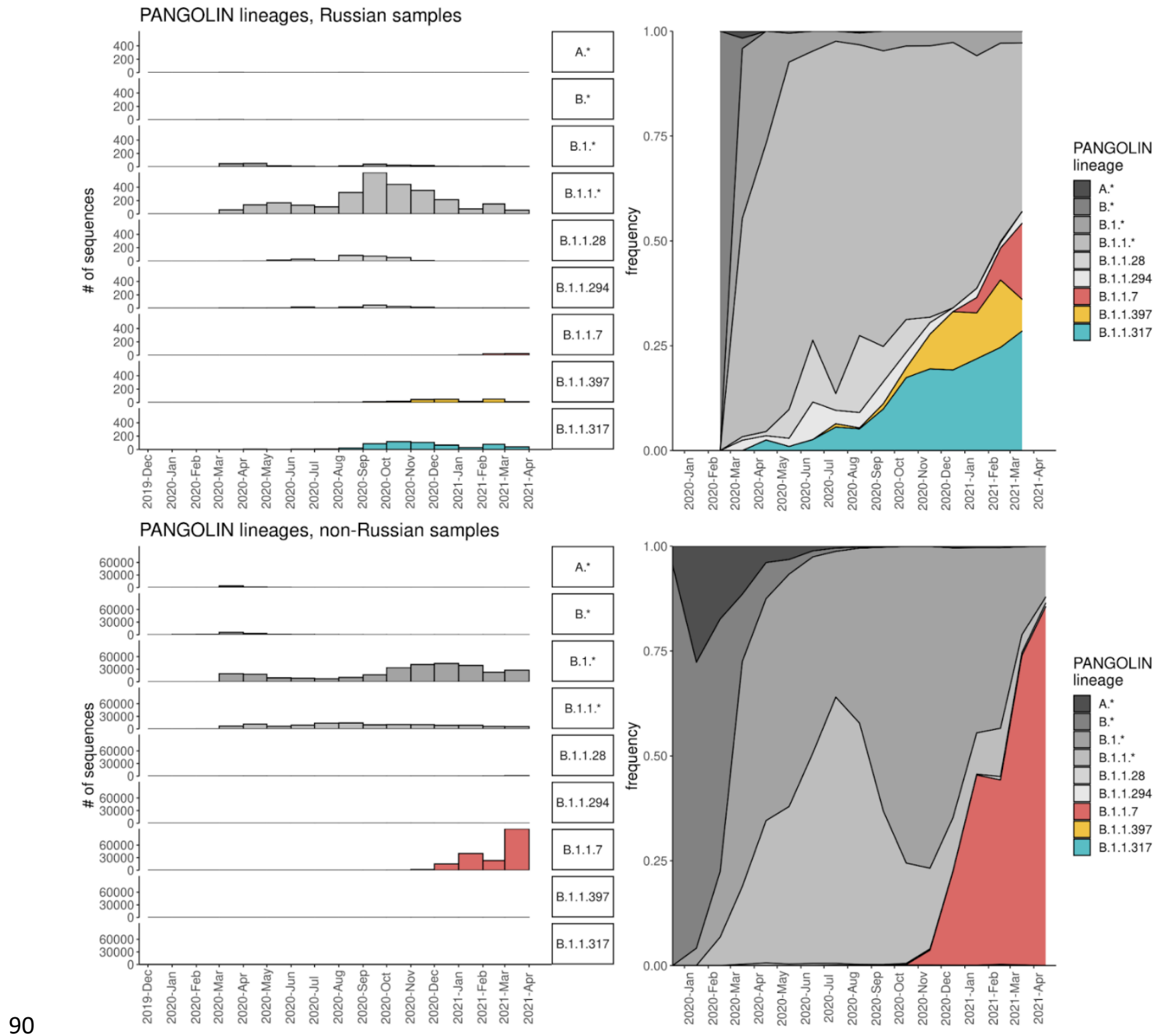

Fig. 1. Dynamics of Pango lineage frequencies in Russia (top row) and among the nonRussian samples in GISAID (bottom row). Asterisks in Pango lineage designations correspond to pooled sets of lineages of that hierarchy level, except those listed in other categories; e.g., B.1.1.* includes B.1.1 and B.1.1.6 but not B.1.1.7 or B.1.1.317. Samples are split into 1 month bins. 
medRxiv preprint doi: https://doi.org/10.1101/2021.05.25.21257695; this version posted May 27, 2021. The copyright holder for this preprint (which was not certified by peer review) is the author/funder, who has granted medRxiv a license to display the preprint in perpetuity.

It is made available under a CC-BY-NC-ND 4.0 International license .

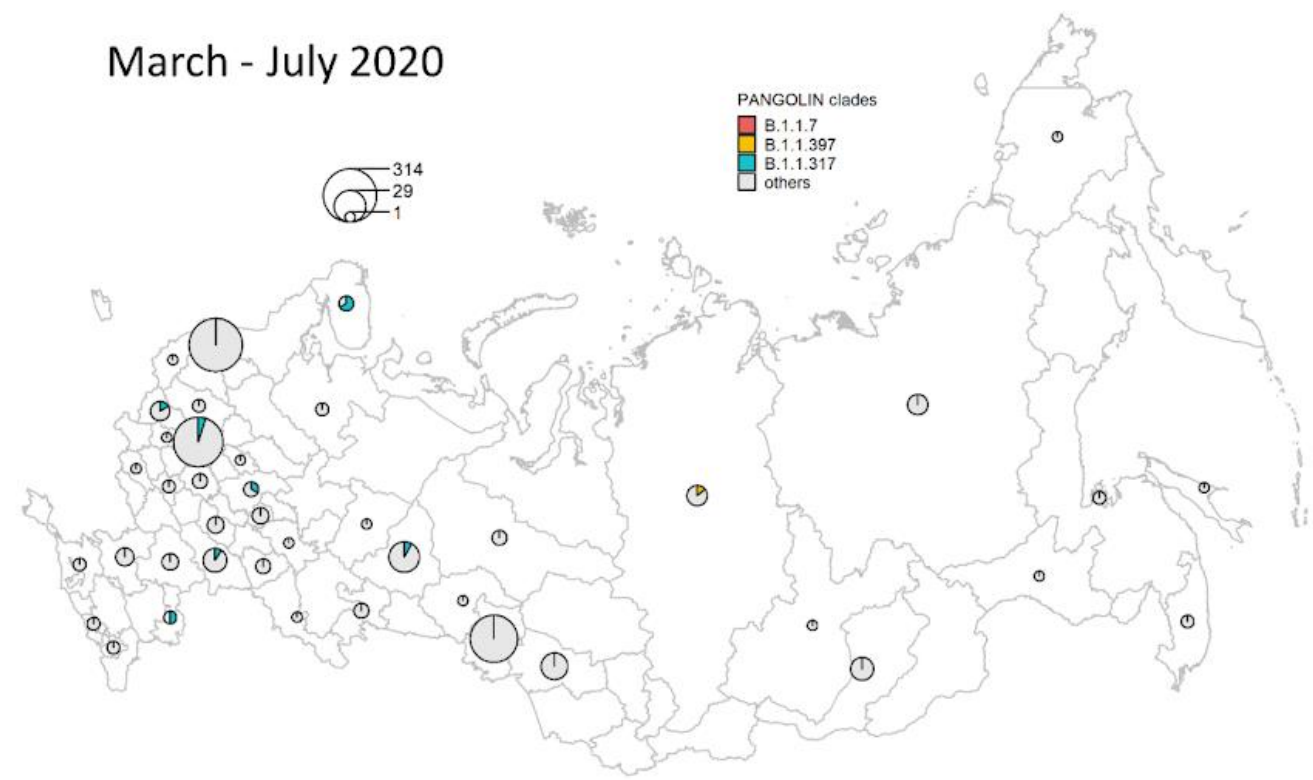

\section{August-October 2020}

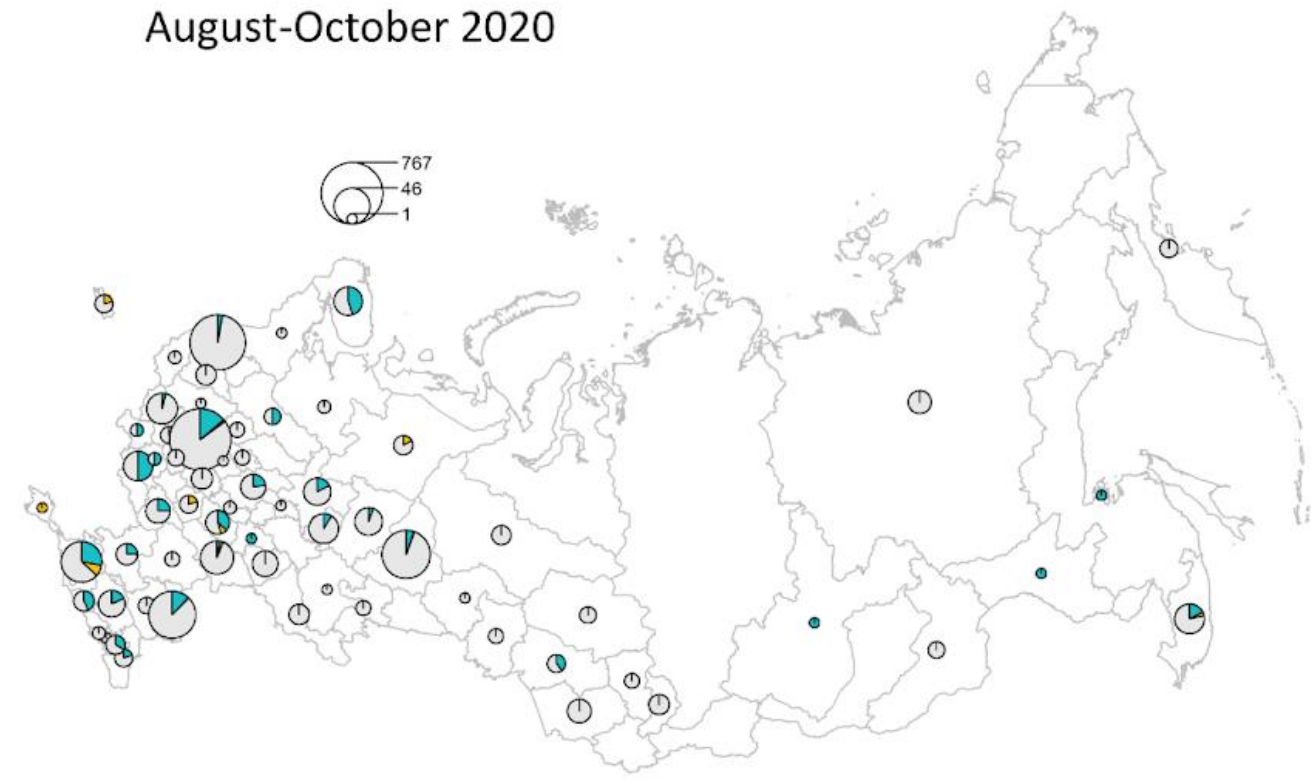

November 2020 - March 2021

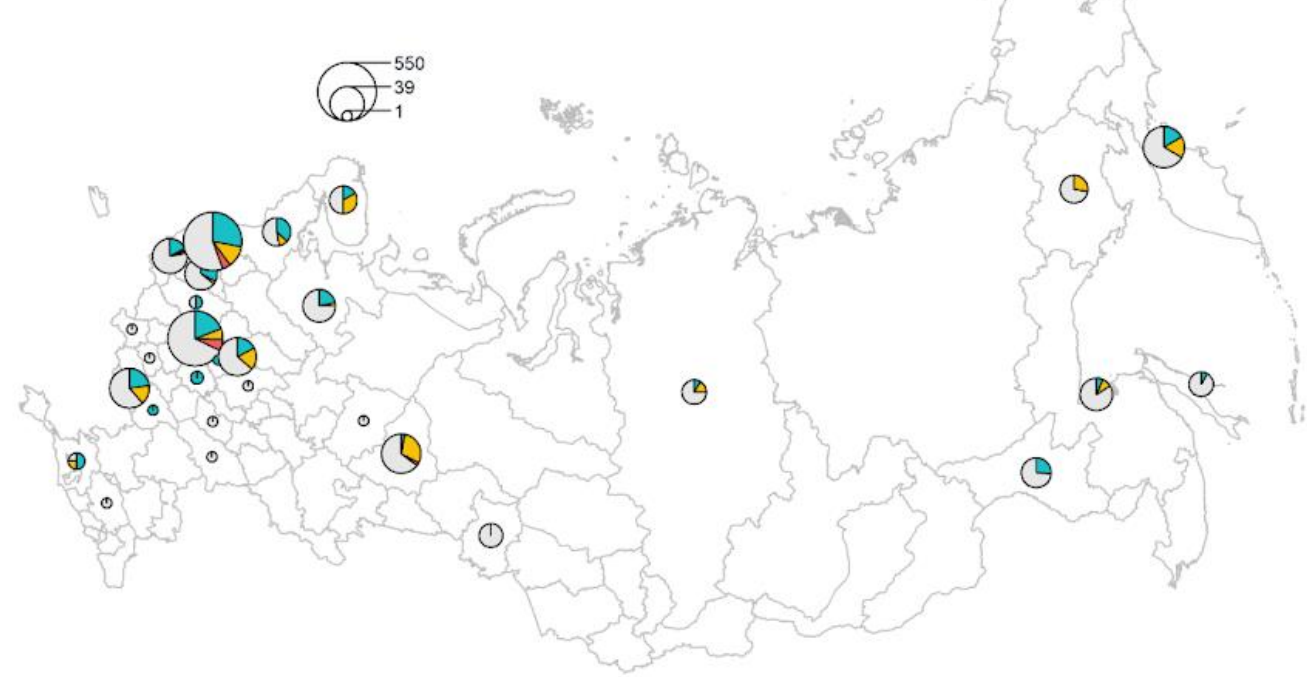


medRxiv preprint doi: https://doi.org/10.1101/2021.05.25.21257695; this version posted May 27, 2021. The copyright holder for this preprint (which was not certified by peer review) is the author/funder, who has granted medRxiv a license to display the preprint in perpetuity.

It is made available under a CC-BY-NC-ND 4.0 International license .

\section{Fig. 2. The spatio-temporal distribution of frequent lineages in Russia.}

To find the non-reference amino acid variants that gained in frequency in Russia, we selected the positions at which the mean frequency of the non-reference variant in Russian samples exceeded $5 \%$ (for the spike) or 10\% (for other proteins) in February-March 2021. We found 21 such positions in spike and 21 such positions in other proteins. Among these changes, two (RdRp:P323L and S:D614G) were fixed early in the global evolution of SARS-CoV-2; other two $(\mathrm{N}: \mathrm{R} 203 \mathrm{~K}$ and $\mathrm{N}: \mathrm{G} 204 \mathrm{R})$ are the lineage-defining mutations of B.1.1.

The frequency dynamics of the derived variants at the remaining 38 positions is shown in Fig. 3. These include the mutations characterizing the B.1.1.7 variant which has been increasing in frequency in Russia since January 2021 (Fig. 1), as well as some of the other globally spreading mutations of concern or interest, including the E484K mutation in spike. However, at many of these sites, the non-reference variants were rare outside Russia (Fig. 3). Most of these variants showed similar temporal dynamics in Moscow and St. Petersburg regions, as well as in the European and Asian parts of Russia (Fig. S1), indicating that their increase in frequency is not a result of sampling bias.

We aimed to identify the high-frequency variants carrying these mutations. Many of these sites were highly homoplasic, and overall we found the resulting phylogenies not to be robust. Instead, we defined the most frequent variants composed of these mutations, independent of the alleles at other sites (Fig. 4).

We considered the allele combinations that were most frequent in Russia in February-March 2021 , and noticed that they belonged to several nested sets. The most frequent combination (99 out of the 461 samples) carried the N:A211V mutation which is characteristic of the B.1.1.317 Pango lineage; the second most frequent combination carried the S:D138Y and ORF8:V62L combination of mutations which are characteristic of the B.1.1.397 lineage; the third combination carried the set of characteristic mutations of B.1.1.7.

Still, there was no one-to-one correspondence between the frequent combinations of mutations and Pango lineages. For example, while the most frequent variant carrying S:M153T was that also including N:M234I, S:D138Y and ORF8:V62L (column 2 in Fig. 4), and classified as Pango lineage B.1.1.397, the variants carrying S:M153T alone, the S:M153T+N:M234I combination and the S:M153T+N:M234I+S:N679K combination were also frequent (columns 4, 9 and 5 in Fig. 4 respectively) but were classified by PANGOLIN as other lineages (B.1.1, B.1.1.141, B.1.1.28 and others). Similarly, while B.1.1.317 is defined by the N:A211V mutation, the frequency of the variant carrying this mutation alone is currently relatively low (column 12 in Fig. 4), while most samples carrying it also carry 8 additional high-frequency mutations, including four potentially important changes in spike (Q675R+D138Y+S477N+A845S; column 1 in Fig. 4). The frequencies of such "non-canonical" combinations of mutations increased throughout 20202021 (Fig. 5).

Finally, we observe three high-frequency combinations of mutations, including the S:E484K mutation of concern as well as other mutations of interest (notably S: $\Delta 140-142, S: \Delta 136-144$ and nsp6: $\Delta 106-108$, also referred to as ORF1a: $\Delta 3675-3677$; columns 7, 8 and 10 in Fig. 4). One of these combinations (column 8 in Fig. 4) has recently got the AT.1 Pango designation. The remaining two (columns 7 and 10) currently lack Pango designations, and are hereafter referred to as B.1.1.v1 and B.1.1.v2. 
medRxiv preprint doi: https://doi.org/10.1101/2021.05.25.21257695; this version posted May 27, 2021. The copyright holder for this preprint (which was not certified by peer review) is the author/funder, who has granted medRxiv a license to display the preprint in perpetuity.

It is made available under a CC-BY-NC-ND 4.0 International license .
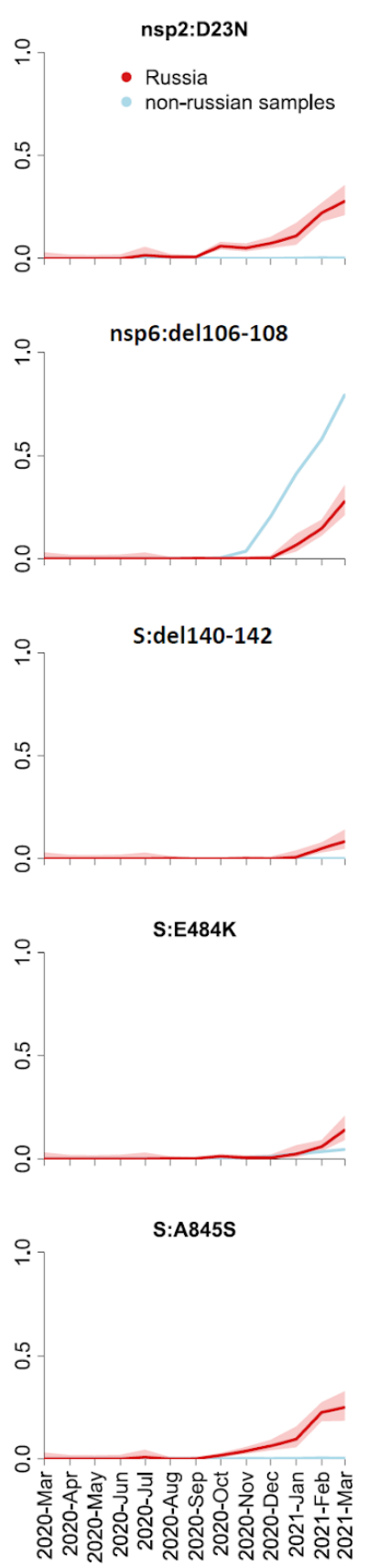

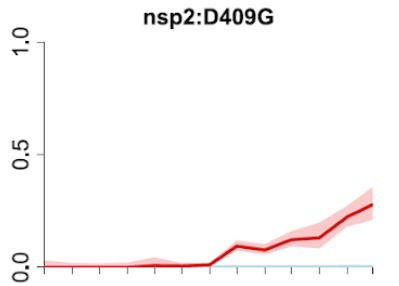

B.1.1.7
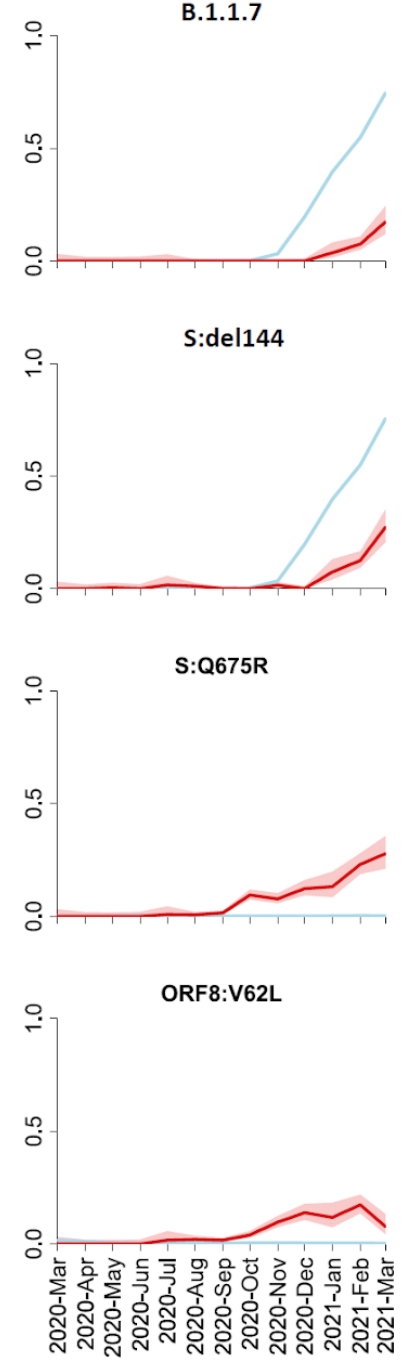

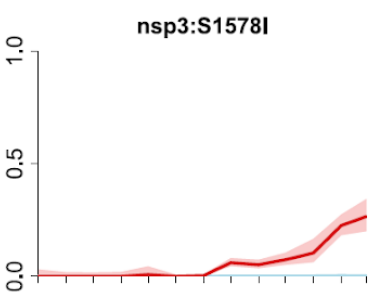

S:P9L
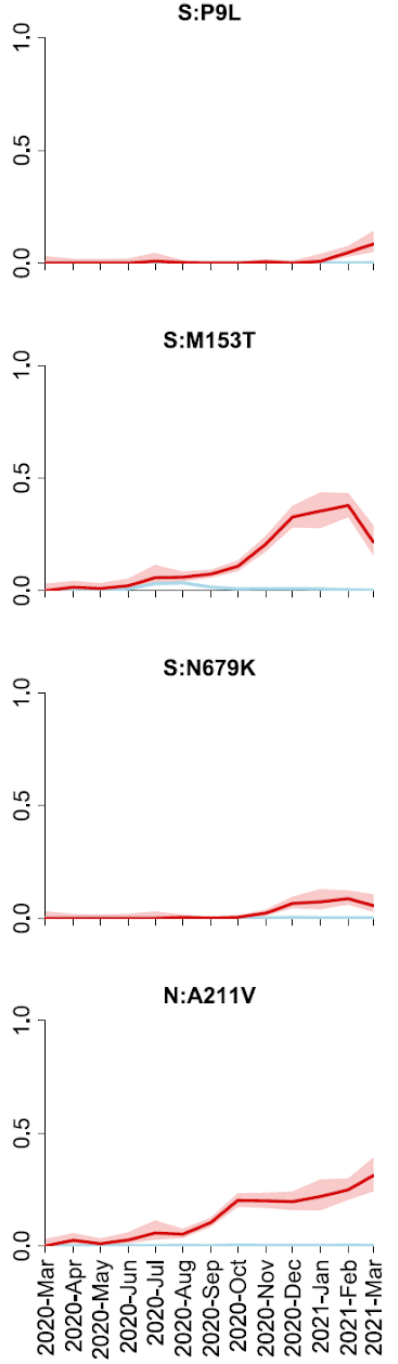
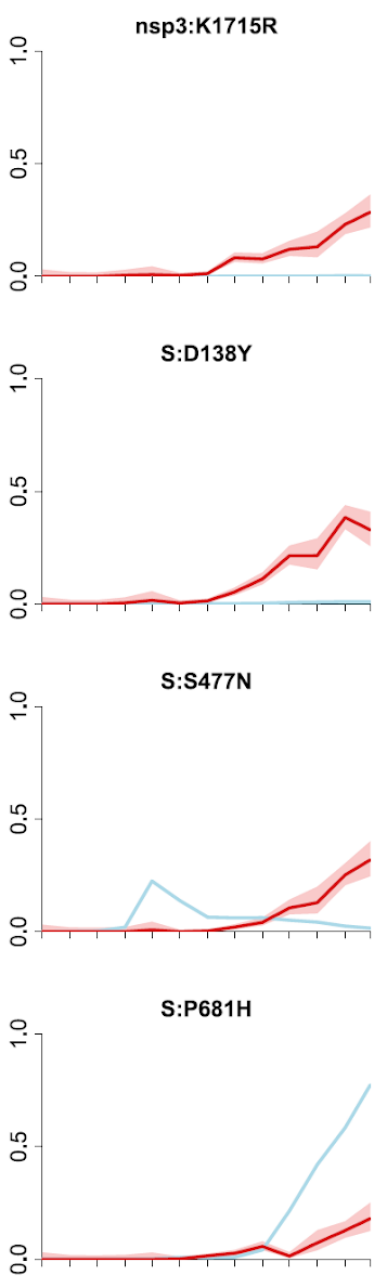

N:M234I

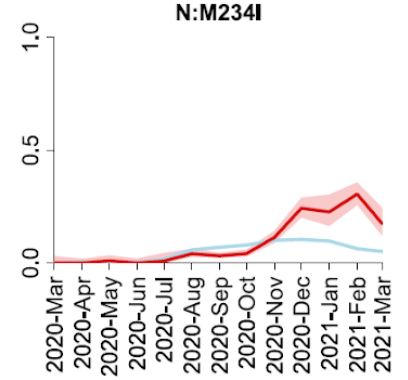

Fig. 3. Frequency dynamics of SARS-CoV-2 amino acid changes. Plots represent changes

in frequency over time for the non-reference amino acid mutations that reached frequencies above $10 \%$ (5\% for the S protein) among the 461 Russian samples obtained in February-March 2021. The frequency of B.1.1.7 is represented by the mutation nsp3:I1412T; deletions nsp6: $\Delta 106-108$ and $S: \Delta 144$ and substitution $S: P 681 \mathrm{H}$ which are a part of $B .1 .1 .7$ as well as other lineages are shown separately; the remaining 14 mutations such that $>70 \%$ of samples carrying them belonged to B.1.1.7 are not shown. Changes in frequency in Russian (red) and non-Russian (blue) samples are shown in one-month time intervals. Shaded areas show 95\% confidence intervals (Wilson score intervals). 
medRxiv preprint doi: https://doi.org/10.1101/2021.05.25.21257695; this version posted May 27, 2021. The copyright holder for this preprint (which was not certified by peer review) is the author/funder, who has granted medRxiv a license to display the preprint in perpetuity.

It is made available under a CC-BY-NC-ND 4.0 International license .



Fig. 4. Variants with high frequencies in Russia in February-March. Horizontal rows represent all positions with non-reference alleles at frequency above $5 \%$ (for spike protein) or $10 \%$ (for other proteins) in Russia in February-March. Columns represent all observed combinations of these variants that included 2 or more samples, with black or colored dots indicating the presence of the non-reference variant. Colors dots represent the variants that are discussed in the text, with the same color coding as in Figs. 1, 2 and 5; blue color corresponds to variants B.1.1.v1 (column 7), AT.1 (column 8) and B.1.1.v2 (column 10). 
medRxiv preprint doi: https://doi.org/10.1101/2021.05.25.21257695; this version posted May 27, 2021. The copyright holder for this preprint (which was not certified by peer review) is the author/funder, who has granted medRxiv a license to display the preprint in perpetuity.

It is made available under a CC-BY-NC-ND 4.0 International license .

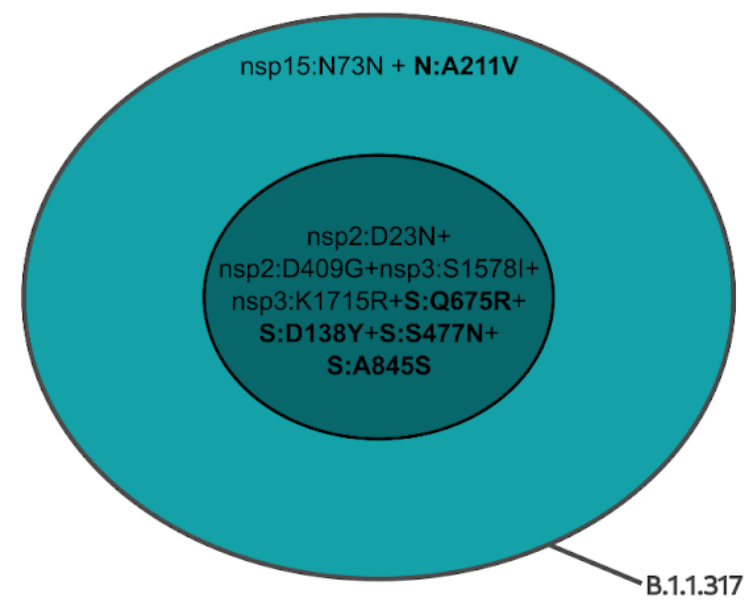

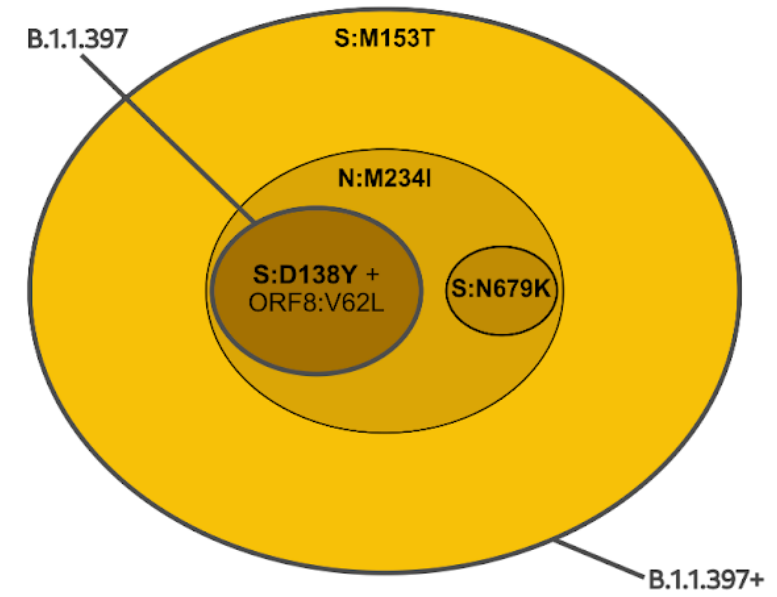

C

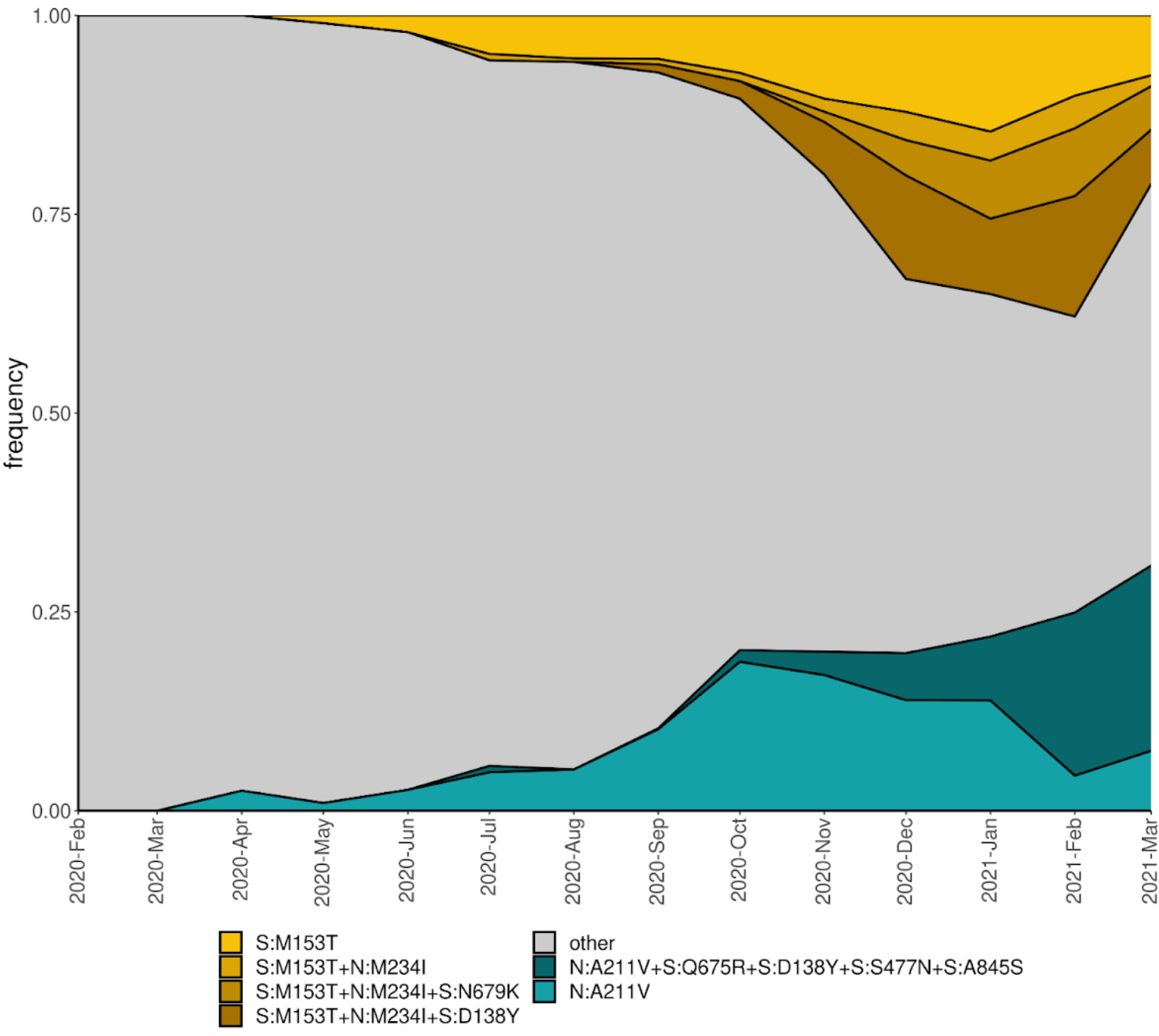

Fig. 5. Mutational composition and frequency dynamics of the B.1.1.317 and B.1.1.397+ lineages. A, B: schematic representation of the B.1.1.317 and B.1.1.397+ lineages. Pango lineage designations are approximate. C: Muller plots representing the frequency dynamics of the corresponding combinations of mutations in Russia. 
medRxiv preprint doi: https://doi.org/10.1101/2021.05.25.21257695; this version posted May 27, 2021. The copyright holder for this preprint (which was not certified by peer review) is the author/funder, who has granted medRxiv a license to display the preprint in perpetuity.

It is made available under a CC-BY-NC-ND 4.0 International license.

To study potential effects of individual mutations composing a variant on the frequency dynamics of this variant, we fit the logistic growth model for the 10 most-frequent combinations of mutations and for $\mathrm{N}: \mathrm{A} 211 \mathrm{~V}$ (which is the 12th most-frequent combination), and compared the dynamics of nested combinations with each other (Figs. 6-8).

The variant carrying just the N:A211V change (largely coincident with the B.1.1.317 Pango lineage) has increased in frequency since the start of the epidemic in Russia. However, since fall 2020, it is being displaced by the variant with 8 additional mutations, including four in spike: $\mathrm{Q} 675 \mathrm{R}+\mathrm{D} 138 \mathrm{Y}+\mathrm{S} 477 \mathrm{~N}+\mathrm{A} 845 \mathrm{~S}$. When the logistic growth model is fit to the N:A211V variant alone, it demonstrates modest growth (Fig. 6A); however, its combination with $\mathrm{S}: \mathrm{Q} 675 \mathrm{R}+\mathrm{D} 138 \mathrm{Y}+\mathrm{S} 477 \mathrm{~N}+\mathrm{A} 845 \mathrm{~S}$ demonstrates a much more rapid frequency increase, with the estimated daily growth rate of $1.93 \%(95 \% \mathrm{Cl}: 1.8 \%-2.06 \%$; Fig. $6 \mathrm{~B})$. While this leads to a frequency increase of the N:A211V mutation independent of the background (Fig. 6C), this suggests that the frequency increase is more likely driven by the $\mathrm{S}: Q 675 R+D 138 Y+S 477 N+A 845 S$ combination than the N:A211V change defining the B.1.1.317 Pango lineage.

\section{A}

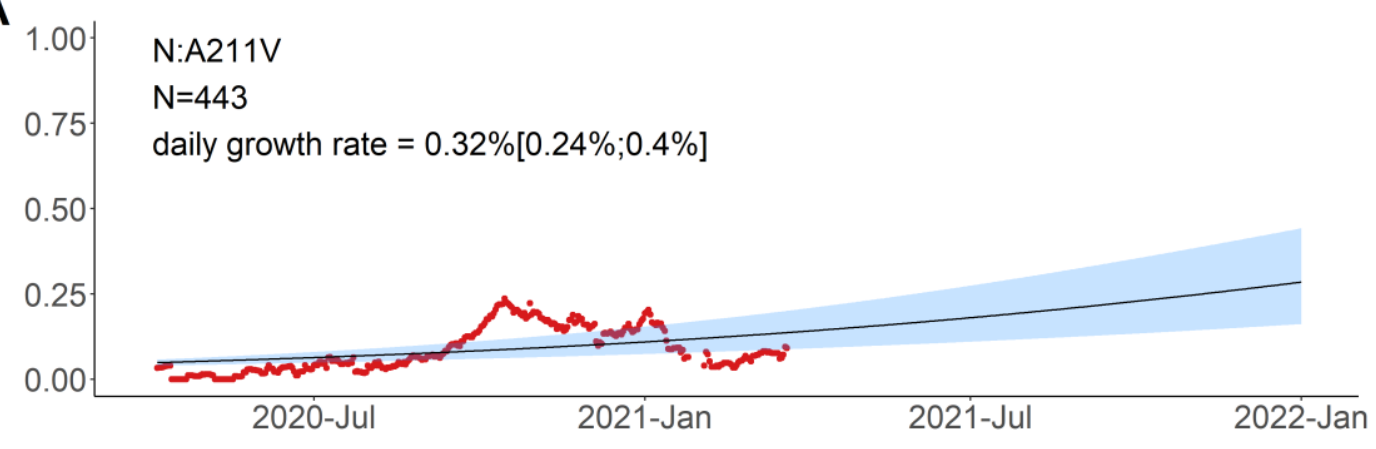

B

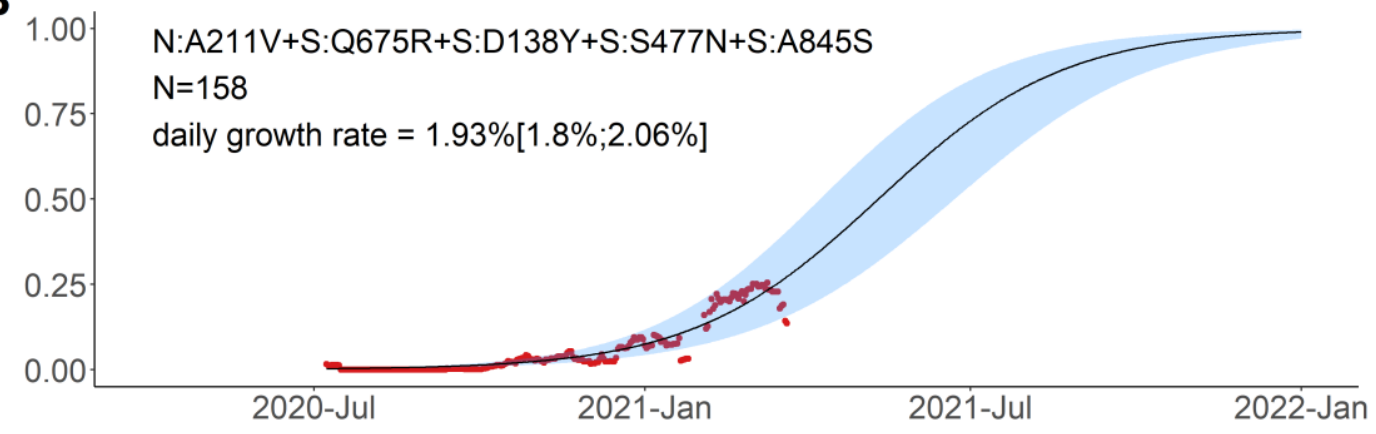

C

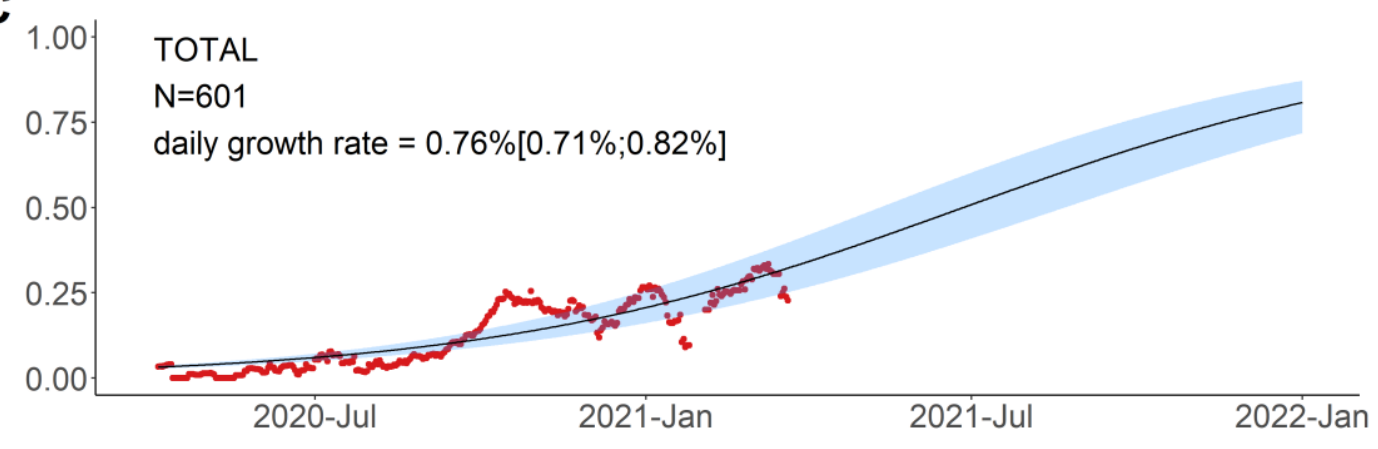


medRxiv preprint doi: https://doi.org/10.1101/2021.05.25.21257695; this version posted May 27, 2021. The copyright holder for this preprint (which was not certified by peer review) is the author/funder, who has granted medRxiv a license to display the preprint in perpetuity. It is made available under a CC-BY-NC-ND 4.0 International license .

183 Fig. 6. Logistic growth model for nested variants defined by amino acid changes in the N:A211V context. Red dots, sliding window 14-day average frequency; shaded area, 95\% confidence interval. Variants are identified according to the presence of the mutations in $S$ and $\mathrm{N}$ proteins; see Fig. 5 for complete lists of mutations in the corresponding variants.

By contrast, the frequency of the S:M153T mutation grows independently of the presence of other mutations from our list (Fig. 7). While subsequent mutations may add to the estimated growth rates, these rates are comparable when the S:M153T mutation occurs alone or in combination with N:M234I, N:M234I+S:N679K, or N:M234I+S:D138Y, and all these combinations are still frequent many months after they all originated (Fig. 5, 7). 
medRxiv preprint doi: https://doi.org/10.1101/2021.05.25.21257695; this version posted May 27, 2021. The copyright holder for this preprint (which was not certified by peer review) is the author/funder, who has granted medRxiv a license to display the preprint in perpetuity.

It is made available under a CC-BY-NC-ND 4.0 International license .

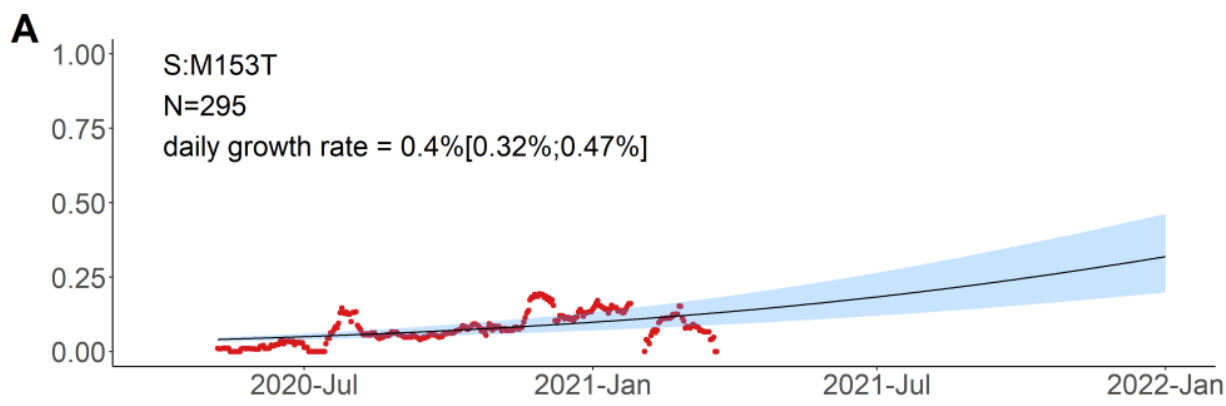

B

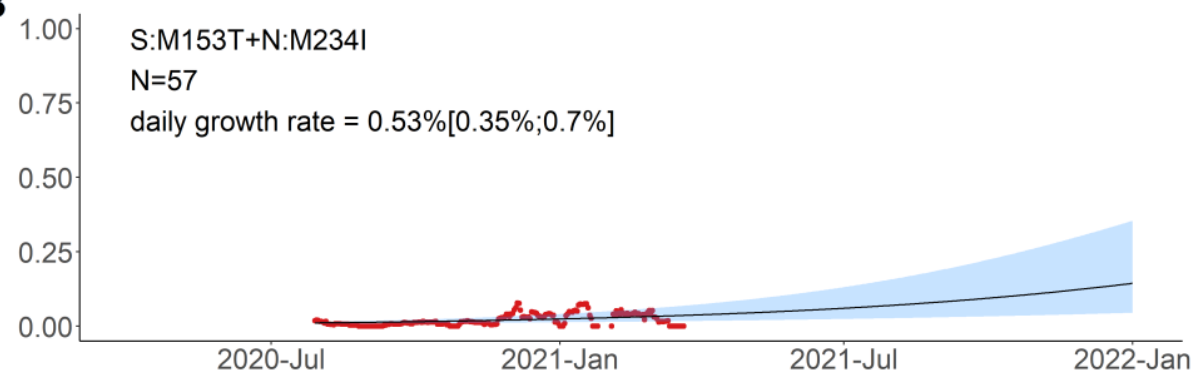

C

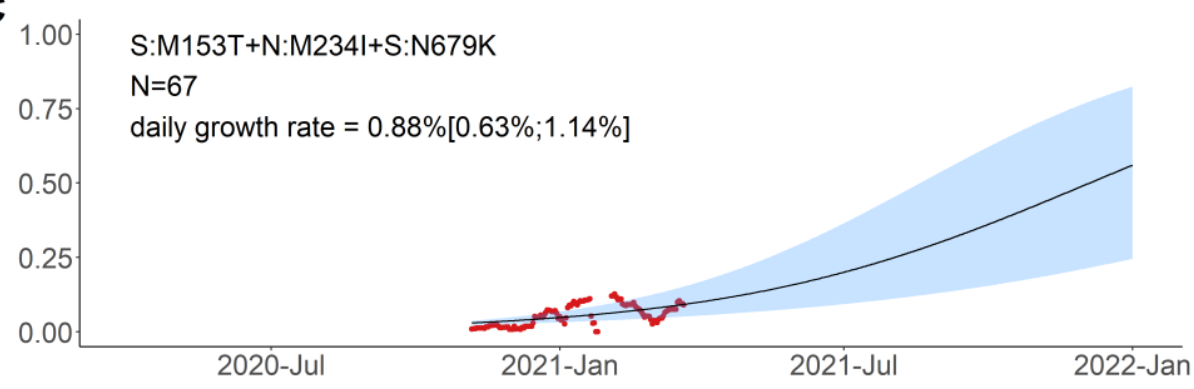

D

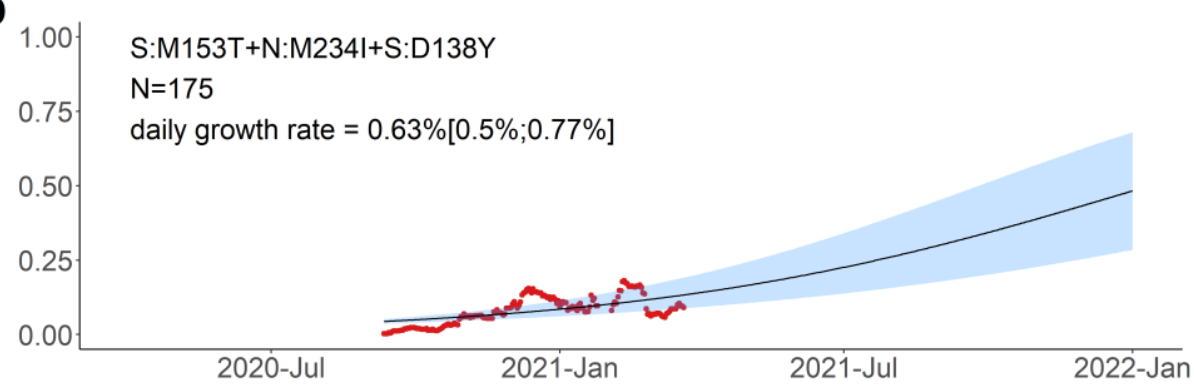

E

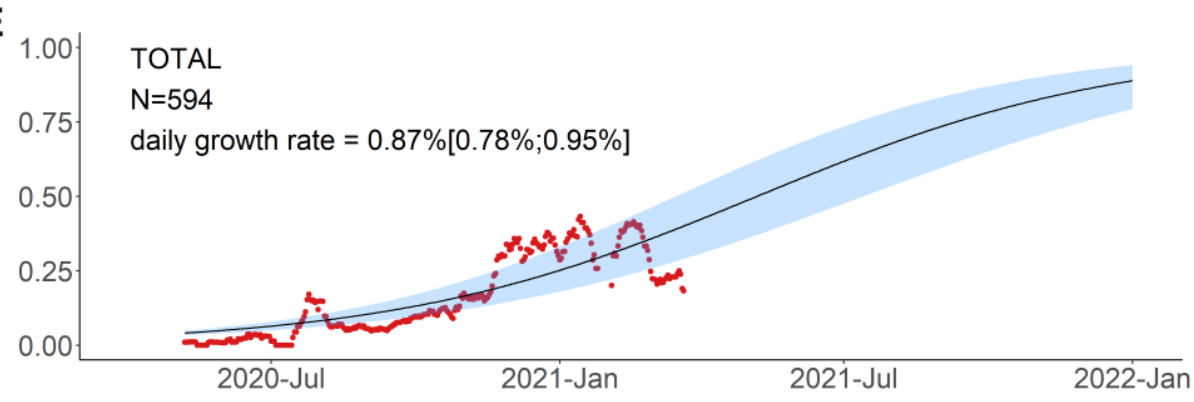

Fig. 7. Logistic growth model for variants defined by amino acid changes in the S:M153T context. Notations are the same as in Fig. 6.

Finally, the five remaining variants which also reached high frequency in February-March carry unnested, although partially overlapping sets of mutations. These include B.1.1.7 (Fig. 8A); a variant carrying the $\mathrm{S}: \mathrm{P} 681 \mathrm{H}$ mutation of interest in the absence of other high-frequency mutations (Fig. 8B); as well as three novel variants carrying the following combinations of 
medRxiv preprint doi: https://doi.org/10.1101/2021.05.25.21257695; this version posted May 27, 2021. The copyright holder for this preprint (which was not certified by peer review) is the author/funder, who has granted medRxiv a license to display the preprint in perpetuity. It is made available under a CC-BY-NC-ND 4.0 International license .

200 mutations: (i) nsp6: $\triangle 106-108+S: P 9 L+S: \Delta 140-142$ (nine of these 14 samples are currently classified by PANGOLIN as B.1.1.74, four as B.1.1, and one as B.1.1.354; this variant is referred to here as B.1.1.v1; Fig.8C); (ii) S:P9L+S: $1136-144+S: E 484 \mathrm{~K}$ (which recently got the AT.1 Pango designation; Fig.8D); and (iii) nsp6: $\Delta 106-108+S: \Delta 144+S: E 484 K$ (currently classified by PANGOLIN as B.1.1; this variant is referred to here as B.1.1.v2; Fig.8E). Variants B.1.1.v1, AT.1 and B.1.1.v2 were only observed in 13-14 samples each, but are of interest because this constitutes an appreciable fraction of samples obtained in February-March (3.0\%, $2.8 \%$ and $2.6 \%$ respectively), and also because they are composed of known mutations of interest or concern. The daily growth rate estimated for these variants by the logistic growth model is in the range of $2.44 \%$ to $7.18 \%$ (Fig. $8 \mathrm{C}-\mathrm{E}$ ). 
medRxiv preprint doi: https://doi.org/10.1101/2021.05.25.21257695; this version posted May 27, 2021. The copyright holder for this preprint (which was not certified by peer review) is the author/funder, who has granted medRxiv a license to display the preprint in perpetuity.

It is made available under a CC-BY-NC-ND 4.0 International license .

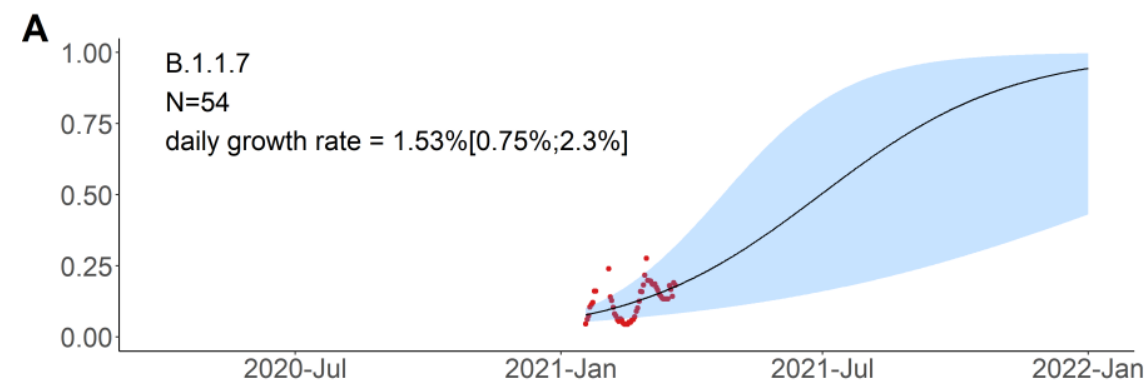

B
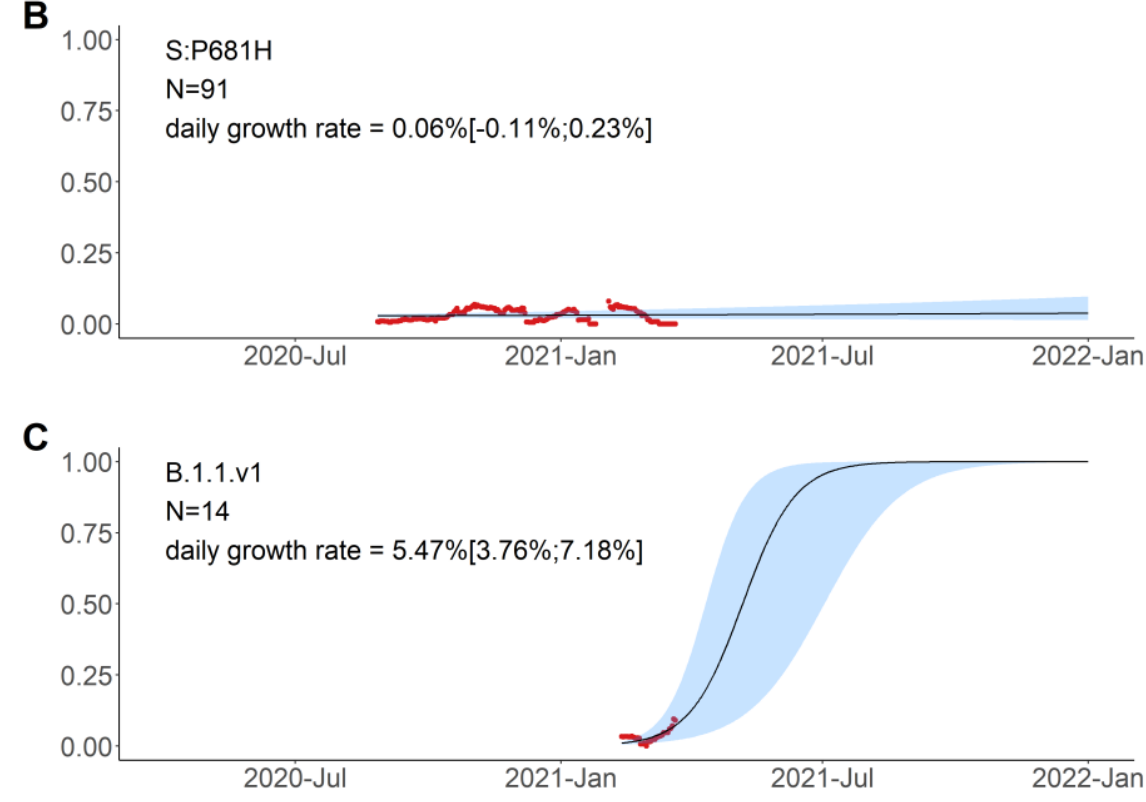

D

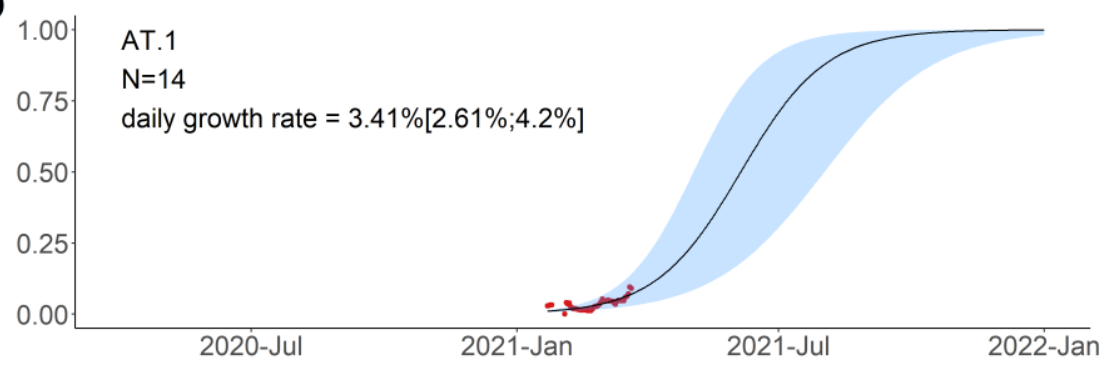

E

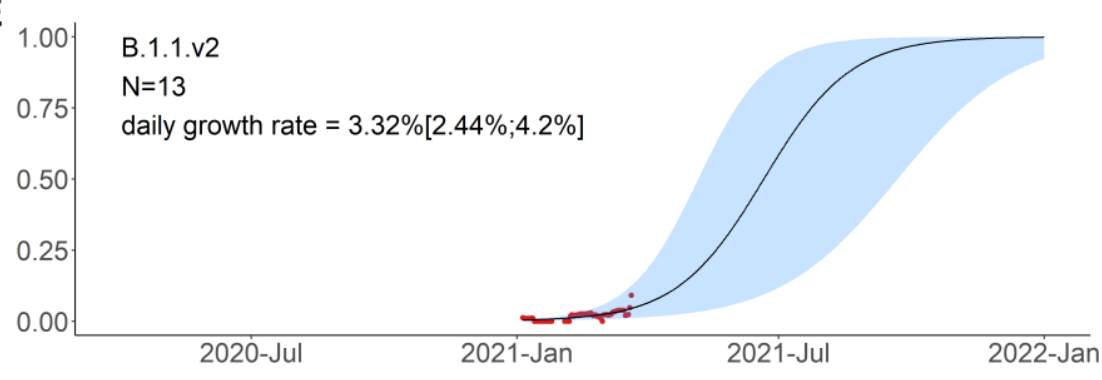

Fig. 8. Logistic growth model for the five remaining amino acid variants with high

frequencies in Russia in February-March. Notations are the same as in Fig. 6. S:P681H has been observed both independently and as part of B.1.1.7; in panel B, the cases of B.1.1.7 are not shown, by excluding the S:P681H+nsp3:I1412T combination.

The continued spread of some of these variants between February-April 2021 is confirmed by community-based PCR testing. To obtain independent frequency estimates, we made use of a 
medRxiv preprint doi: https://doi.org/10.1101/2021.05.25.21257695; this version posted May 27, 2021. The copyright holder for this preprint (which was not certified by peer review) is the author/funder, who has granted medRxiv a license to display the preprint in perpetuity.

It is made available under a CC-BY-NC-ND 4.0 International license .

PCR system sensitive to the presence of nsp6: $\Delta 106-108$ and $S: \Delta 69-70$ deletions (see Methods) to detect the B.1.1.7, B.1.1.v1 and B.1.1.v2 variants. Specifically, S: $\Delta 69-70+n s p 6: \Delta 106-108+$ samples correspond to B.1.1.7, while $S: \Delta 69-70$ nsp6: $\Delta 106-108^{+}$samples correspond to either the B.1.1.v1 or the B.1.1.v2 variant (Fig. 4). While the frequency estimates were highly uncertain (Table 1), they indicate that B.1.1.7, and one or both of variants B.1.1.v1 and B.1.1.v2, were wide-spread in April (Fig. 9, Table 1). A considerable fraction (59.6\%) of PCR samples from February and March were included in our main analysis, as their sequences were in GISAID. However, the frequency increase was also observed in the 136 PCR samples for which no sequencing data was available (Fig. S2), providing independent validation of the NGS results. Similarly, it was observed when the PCR tests only for St. Petersburg were analysed (Fig. S3, S4), indicating that the prevalence of these variants increases at least in this city as opposed to being an artefact of changing sampling between regions.
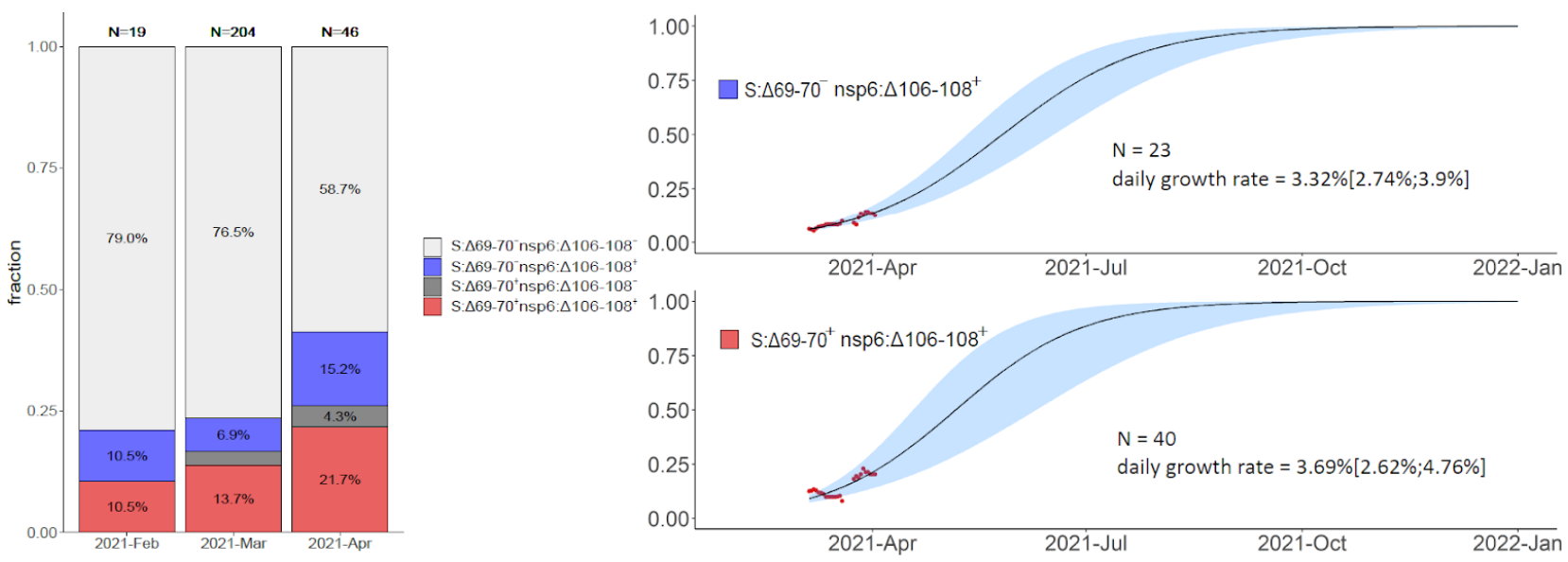

Figure 9. Frequencies of $S: \Delta 69-70$, nsp6: $\Delta 106-108$, and their combination in Russia in Feb-Apr 2021 based on PCR data. S: $\triangle 69-70+n s p 6: \Delta 106-108+$ samples correspond to B.1.1.7, and $S: \Delta 69-70$ nsp6: $\Delta 106-108$ samples correspond to B.1.1.v1 or B.1.1.v2. The rare instances of $S: \Delta 69-70+$ nsp6: $\Delta 106-108$ probably correspond to false positive $S: \Delta 69-70$ detection. Notations for logistic curves are the same as in Fig. 6.

Table 1. Frequencies of (B.1.1.v1 or B.1.1.v2) and B.1.1.7 estimated from PCR data. The point estimate and the $95 \%$ confidence intervals (Wilson score intervals) are shown.

\begin{tabular}{|l|l|l|l|}
\hline & $2021-\mathrm{Feb}$ & $2021-\mathrm{Mar}$ & $2021-\mathrm{Apr}$ \\
\hline $\begin{array}{l}\text { nsp6: } \Delta 106-108+\mathrm{S}: \Delta 69-70-(B .1 .1 . v 1 \\
\text { or B.1.1.v2) }\end{array}$ & $\begin{array}{l}10.5 \%(2.3 \%- \\
31.4 \%)\end{array}$ & $\begin{array}{l}6.9 \%(4.1 \%- \\
11.2 \%)\end{array}$ & $\begin{array}{l}15.2 \%(7.6 \%- \\
28.2 \%)\end{array}$ \\
\hline nsp6: $\Delta 106-108+$ S: $\Delta 69-70+(B .1 .1 .7)$ & $\begin{array}{l}10.5 \%(2.9 \%- \\
31.4 \%)\end{array}$ & $\begin{array}{l}13.7 \%(9.7 \%- \\
19.1 \%)\end{array}$ & $\begin{array}{l}21.7 \%(12.3 \%- \\
35.6 \%)\end{array}$ \\
\hline
\end{tabular}

\section{Mutational composition of the high-frequency variants}

241 In this section, we discuss the mutations that constitute the variants spreading in Russia.

B.1.1.317. This lineage is defined by the presence of the N:A211V mutation. Changes at nucleocapsid position 211 experience both persistent (according to the FEL model of HyPhy 10 ) and episodic (according to the MEME modelı) positive selection both in the globalı and in the Russian dataset $(p=0.0396$ for the MEME model and $p=0.0268$ for the FEL model, the likelihood-ratio test), as well as a rapid increase in frequency of non-reference variants in the 
medRxiv preprint doi: https://doi.org/10.1101/2021.05.25.21257695; this version posted May 27, 2021. The copyright holder for this preprint (which was not certified by peer review) is the author/funder, who has granted medRxiv a license to display the preprint in perpetuity.

It is made available under a CC-BY-NC-ND 4.0 International license .

global dataseti2. While the global frequency of $211 \mathrm{~V}$ has remained low $(<0.4 \%)$, in Russia, it has reached $26.9 \%$ in February-March 2021 . According to immunoinformatic analysis, site N:211 is included in one of the four regions of the nucleocapsid protein with the highest affinity to multiple MHC-I alleles ${ }^{13}$. Nevertheless, the frequency of the variant carrying the N:A211V mutation alone has declined since October 2020 (Fig. 5), suggesting that it is unlikely to confer transmission advantage against the background of other currently frequent variants (Fig. 6).

A rapidly spreading subclade within B.1.1.317 carries the (Q675R+D138Y+S477N+A845S) combination of changes in spike. Two of these mutations are of interest. S:D138Y, first described as one of the lineage-defining mutations of the P.1 lineage ${ }^{14}$, is a change in the $\mathrm{N}$ terminal domain (NTD) of spike. Site 138 is adjacent to the NTD antigenic supersite, and together with other NTD mutations of P.1, S:D138Y was suggested to be the cause of disruption of binding with mAb159 ${ }^{15}$ which is one of the most potent inhibitory antibodies ${ }^{16}$. S:S477N is positioned in the receptor-binding motif (RBM) of the S-protein near the antibody binding site (Fig. 10) and was reported to promote resistance to multiple antibodies and plasma from convalescent patients ${ }_{17.18}$. Additionally, S477N is thought to increase ACE2 binding ${ }^{19}$. It is one of the lineage-defining mutations of the B.1.160 (20A.EU2) variant of interest prevalent in Europe in Autumn 2020²0, and the only one among them to occur in the S-protein; it also defines one of the two subclades of the B.1.526 variant of interest currently spreading in the USA ${ }^{21.22}$. S:Q675R is located at the central part of S1 (Fig. 10), and S:A845S, in S2; the significance of these two mutations is unknown.

B.1.1.397+. S:M153T is a characteristic mutation of B.1.1.397, which also comprises several other mutations. However, the frequency of S:M153T in Russia also increases in the absence of these other mutations (Fig. 7). This increase has been ongoing since late spring 2020 (Fig. 5), and has been noticed in Russia 2324. S:M153T, however, has remained rare outside Russia. S:153 is the first position of the 6-amino acid insertion specific to SARS-CoV-2 and some closely related bat betacoronaviruses that was absent in SARS-CoV ${ }_{25}$. While the effect of S:M153T on antigenic properties is unknown, S:153 is a part of the N3 loop of the NTD. This loop is a part of the NTD antigenic supersite (Fig. 10; 2 ), and nearby residues, including S:152, were recently shown to bind highly neutralizing 4A8 antibody from a convalescent patient ${ }^{27}$. Besides Russia, S:M153T is prevalent in Kazakhstan² which has a long border with Russia, suggesting common ancestry of this change in these countries.

The most frequent subclade within B.1.1.397+, and the one with some evidence for an independent increase in frequency (Fig. 7), is defined by the presence of two additional mutations of interest: S:D138Y discussed above in the context of the B.1.1.317 lineage (but acquired in the B.1.1.397 lineage independently); and N:M234I. Position N:234 is a part of a disordered linker domain of the nucleocapsid protein². Outside B.1.1.397, the N:M234I change has also occurred independently in several lineages that attracted attention. It is among the lineage-defining mutations of the B.1.160 (20A.EU2) lineage as well as the B.1.526 lineage that increases in frequency in the USA at rates comparable to those of B.1.1.721. It is also one of the changes defining a newly detected lineage (preliminarily identified as B.1.x) which also contains S:N501Y and S:P681H and seems to spread rapidly in the USA $\mathrm{N}: \mathrm{M} 234 \mathrm{I}$ in several variants of interest may reflect its impact on at least one of multiple functions of the $\mathrm{N}$ protein ${ }^{31}$.

Other notable variants. The five other combinations of mutations observed at high frequencies in Russia in February-March 2021 are B.1.1.7, the best-known variant with increased transmissibility; the variant carrying the $\mathrm{S}: \mathrm{P} 681 \mathrm{H}$ mutation alone; and three novel variants.

$\mathrm{S}: \mathrm{P} 681 \mathrm{H}$ is one of the nine spike changes that characterize the rapidly spreading B.1.1.7 lineages; however, it is absent from the two other lineages of concern, B.1.351 and P.1, indicating that it is not essential for increased transmissibility. The 681 position is adjacent to the furin cleavage site; this site is absent in non-human CoV, and is assumed to have contributed to pathogenicity in humans ${ }^{32}$. Changes at this position experience both persistent and episodic positive selection ${ }^{12}$. $\mathrm{P} 681 \mathrm{H}$ appears to increase in frequency globally ${ }^{\underline{3}}$, although it is hard to 
medRxiv preprint doi: https://doi.org/10.1101/2021.05.25.21257695; this version posted May 27, 2021. The copyright holder for this preprint (which was not certified by peer review) is the author/funder, who has granted medRxiv a license to display the preprint in perpetuity.

It is made available under a CC-BY-NC-ND 4.0 International license .

disentangle this increase from that of the other changes constituting the rapidly spreading B.1.1.7 lineage. We find that the frequency of this mutation in Russia in the absence of other B.1.1.7 mutations does not increase (Fig. 8), indicating that it does not increase transmissibility 302 by itself.

The three remaining high-frequency variants with evidence for rapid frequency increase carry combinations of the following high-frequency mutations: S:P9L, S: $\Delta 140-142$ (or S: $\Delta 136-144$ ), S:E484K, and nsp6: $\Delta 106-108$. The sets of mutations in these variants are in conflict (i.e., not nested within each other; Fig. 4), indicating that at least some of these mutations emerged in them independently. These mutations are of interest or concern. Specifically, S:E484K (present in AT.1 and B.1.1.v2) is involved in multiple variants of concern including the B.1.351

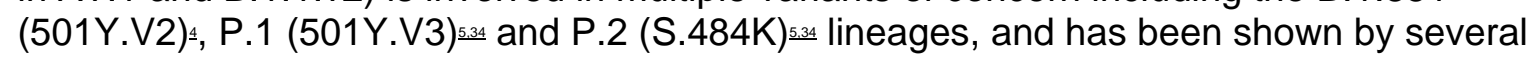
groups to cause escape from neutralizing antibodies $35-37$. nsp6: $\triangle 106-108$ (also referred to as ORF1a: $\Delta 3675-3677$, and present in B.1.1.v1 and B.1.1.v2) is a part of all three variants of concern. S: $\Delta 140-142$ (present in B.1.1.v1), S: $\Delta 144$ (present in B.1.1.v2) and S: $\Delta 136-144$ (present in AT.1) are distinct deletions at a recurrent deletion region of the spike glycoprotein which confer resistance to neutralizing antibodies ${ }^{\text {s. }}$. 
medRxiv preprint doi: https://doi.org/10.1101/2021.05.25.21257695; this version posted May 27, 2021. The copyright holder for this preprint (which was not certified by peer review) is the author/funder, who has granted medRxiv a license to display the preprint in perpetuity.

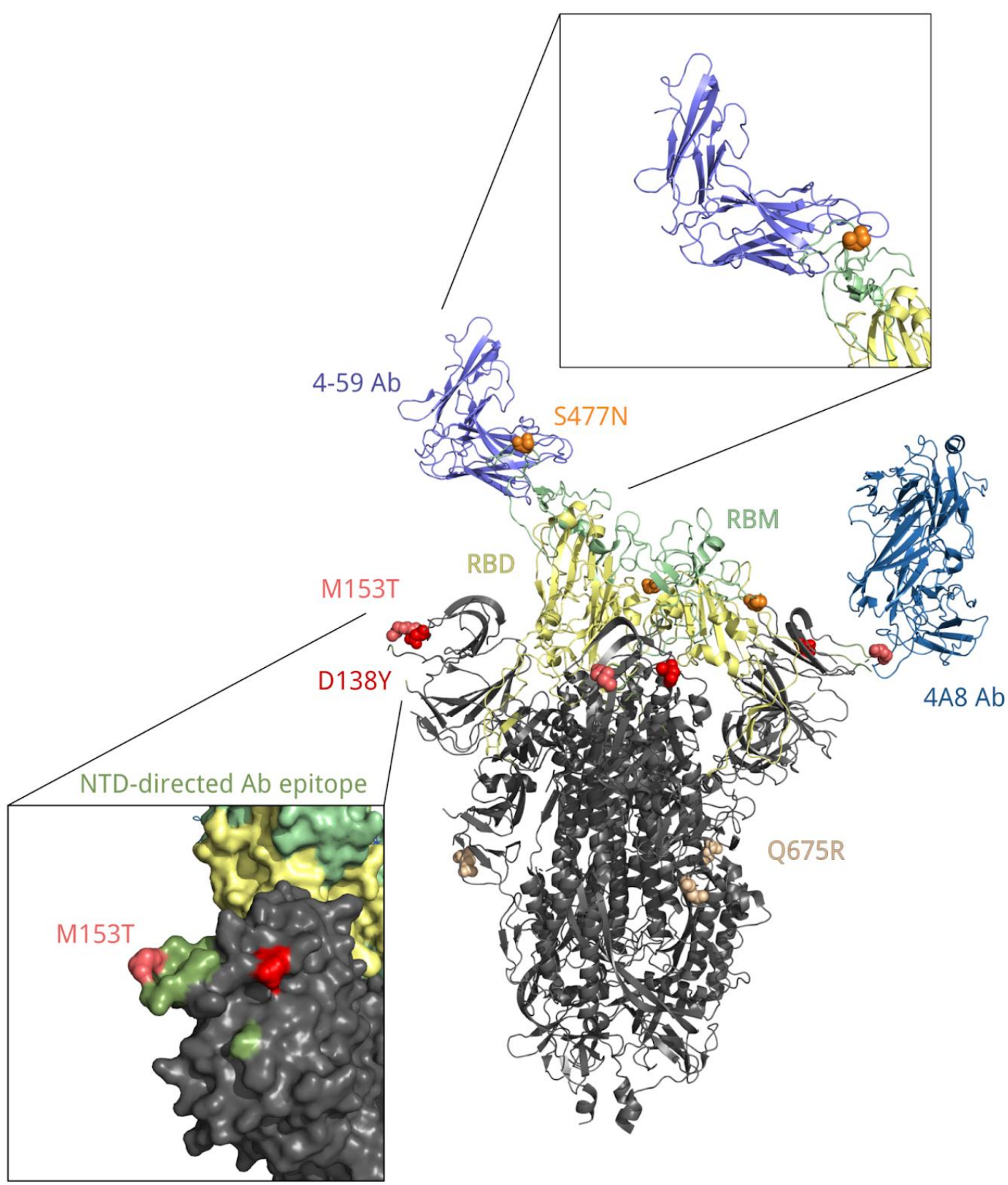

Fig. 10. Position of residues 138, 153, 477 and 675 in the spatial structure of the $S$ protein bound with 4A8 and 4-59 antibodies (PDB IDs: 7c2I and 7czX). Each of these residues is colored in its own color. Yellow, receptor binding domain; green, receptor binding motif; ocean blue, heavy chain of the 4A8 antibody; blue, heavy chain of the 4-59 antibody; olive, antibody binding epitope.

Russia has been relatively well isolated in the course of COVID-19 pandemic: both the first cases of COVID-19 and the arrival of variants of concern, notably the B.1.1.7, have happened here later than in many European countries ${ }^{8.39}$. Together with the large size of the outbreak in Russia, such isolation could have created conditions for emergence of novel important domestic variants. 
medRxiv preprint doi: https://doi.org/10.1101/2021.05.25.21257695; this version posted May 27, 2021. The copyright holder for this preprint (which was not certified by peer review) is the author/funder, who has granted medRxiv a license to display the preprint in perpetuity.

It is made available under a CC-BY-NC-ND 4.0 International license .

A steady increase in frequency of lineages B.1.1.317 and B.1.1.397+, as well as the presence of multiple mutations with potential effect on antigenic properties, notably S:D138Y, merit classification of these two lineages as variants of interest 0.04 . Nevertheless, the rate of spread of

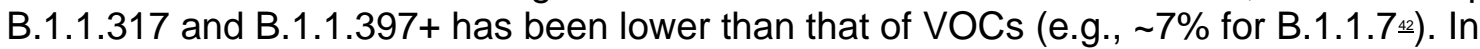
particular, while B.1.1.317 has been observed in Russia since April 2020, the subclade of B.1.1.317 carrying the three spike mutations, since July 2020, and B.1.1.397+, since April 2020, all these lineages have remained at frequencies below 30\% in Russia, and the logistic growth rates estimated by our model are all below $2 \%$ (Fig. 6-8). Besides, these variants are currently missing spike changes L452R, E484K or N501Y which occur in other VOCs 4 .

The combinations of mutations seen in the three variants that emerged in 2021, AT.1, B.1.1.v1 and B.1.1.v2 (Fig. 8C-E), look more suspicious, because their estimated rate of frequency increase is higher and because they include mutations with known effects and occurring in other variants of interest or concern. While little can be told about their frequency dynamics on the basis of the currently available data, they require careful monitoring.

\section{Methods}

Dataset preparation. 1,060,545 sequences of SARS-CoV-2 were downloaded from GISAID on April 15, 2021 (Supplementary File 2) and aligned with MAFFT 4 $v 7.45324$ against the reference genome Wuhan-Hu-1/2019 (NCBI ID: MN908947.3) with --addfragments --keeplength options. 100 nucleotides from the beginning and from the end of the alignment were trimmed. After that, we excluded sequences (1) shorter than $29,000 \mathrm{bp}$, (2) with more than 3,000 (for Russian sequences) or 300 (for all other countries) positions of missing data (Ns), (3) excluded by Nextstrain ${ }^{44}$, (4) in non-human animals, (5) with a genetic distance to the reference genome more than four standard deviations from the epi-week mean genetic distance to the reference, or (6) with incomplete collection dates. As our focus was on the spread of lineages in Russia, and since Russia is relatively poorly sampled, we chose a less stringent threshold at step (2) for Russian compared to non-Russian sequences in order to keep more Russian data in the dataset. To this dataset, we added the 1,645 Russian sequences described in our earlier study ${ }^{45}$ and 344 samples produced by the CoRGI consortium which had not been yet available in GISAID on April 15 (but have been deposited to GISAID since then). The final dataset consisting of 830,249 sequences, including 4,487 Russian samples, was then annotated by the PANGOLIN package (v2.3.8). For the categories in Fig. 1, we selected Pango lineages represented by at least 100 Russian samples (there were six such lineages: B.1, B.1.1, B.1.1.397, B.1.1.28, B.1.1.317 and B.1.1.294), added the two earliest lineages $A$ and $B$ and the VOC lineage B.1.1.7, and aggregated A, B, B.1 and B.1.1 with lineages nested in them except those included in other categories into A.*, B. ${ }^{*}, B .1 .^{*}$ and B.1.1. ${ }^{*}$, respectively.

Data analysis. To trace the frequency dynamics of mutations, for each non-reference nucleotide at each position in each month, we calculated the fraction of samples with this nucleotide among all samples where this position contained an ambiguous nucleotide. We did this separately for the Russian and non-Russian samples, and selected changes with frequency more than $5 \%$ in S protein and more than 10\% in other proteins in February-March 2021 (a total of 461 sequences) in Russian samples for consideration. Calculations were performed with custom Perl and R scripts. Wilson score intervals were estimated using Hmisc $R$ package ${ }^{46}$, and results were visualised with the ggplot2 package ${ }^{4 z}$ of $R$ language ${ }^{48}$. Upset plots were built with the UpSetR package ${ }^{49}$ for $R$. Logistic growth models were fit to frequencies of each variant averaged across 14-days sliding windows with $\mathrm{nls}()$ function of $\mathrm{R}$ language ${ }^{48}$. Only windows with total number of samples $>20$ were taken into account. Confidence intervals for estimated parameters were obtained with confint2 function from nlstools $R$ package ${ }^{\underline{s 0}}$, similar to $\stackrel{42}{.}$. Results were visualised with $\mathrm{R}$ packages ggplot2 ${ }^{47}$, tidyverse ${ }^{51}$ and gridExtra ${ }^{52}$.

To estimate positive selection, we employed MEME and FEL models implemented in the HyPhy package ${ }^{10.11}$. For this analysis, we added Russian sequences with incomplete collection dates to 
medRxiv preprint doi: https://doi.org/10.1101/2021.05.25.21257695; this version posted May 27, 2021. The copyright holder for this preprint (which was not certified by peer review) is the author/funder, who has granted medRxiv a license to display the preprint in perpetuity.

It is made available under a CC-BY-NC-ND 4.0 International license .

the main dataset, which resulted in 5006 Russian sequences. The tree for the selection analysis was built upon the whole-genome alignment of Russian sequences with the RAxML package v.8.0.26 (model GTRCAT) 호.

Mapping residues onto the S-protein structure. To visualize spike mutations, we utilized two different spike protein structures, corresponding to S-protein in complex bound with 4A8 (PDB ID: 7c2I) or with P5A-1B9 (PDB ID: 7czx) antibody. The NTD antibody binding epitope is defined as in 26. The two structures were structurally aligned and visualized with Open-Source PyMOL 54 .

PCR data. Community-based PCR tests aimed at detection of S: $\Delta 69-70$ and nsp6: $\Delta 106-108$ deletions were performed for 739 samples. We further analysed only those samples for which both tests were performed and produced unambiguous results. There were 269 such samples from 22 regions (including 170 from Saint Petersburg, 43 from Sverdlovsk Oblast, and 12 from Leningrad Oblast) obtained between February-April, 2021. For S: $\Delta 69-70$ detection $\$$, we used the Yale69/70del RT-PCR assay described elsewhere. For nsp6: $\Delta 106-108$ detection, we used a newly designed RT-PCR assay. 133 of these 269 samples were also sequenced (sequence data made available through GISAID); for 126 of them (94.7\%), the results on the presence of S: $\triangle 69-70$ and nsp6: $\triangle 106-108$ were consistent between the NGS and PCR data, indicating that our PCR tests are highly specific.

\section{${ }_{406}$ References}

4071. Korber, B. et al. Tracking Changes in SARS-CoV-2 Spike: Evidence that D614G Increases

408 Infectivity of the COVID-19 Virus. Cell 182, 812-827.e19 (2020).

4092. Volz, E. et al. Evaluating the Effects of SARS-CoV-2 Spike Mutation D614G on Transmissibility

410 and Pathogenicity. Cell 184, 64-75.e11 (2021).

4113. ECDPC. Rapid increase of a SARS-CoV-2 variant with multiple spike protein mutations

412 observed in the United Kingdom. (2020).

4134. Tegally, H. et al. Emergence and rapid spread of a new severe acute respiratory syndrome-

414 related coronavirus 2 (SARS-CoV-2) lineage with multiple spike mutations in South Africa.

$415 \quad$ medRxiv 2020.12.21.20248640 (2020) doi:10.1101/2020.12.21.20248640.

4165. Genomic characterisation of an emergent SARS-CoV-2 lineage in Manaus: preliminary findings.

417 Virologica/ https://virological.org/t/genomic-characterisation-of-an-emergent-sars-cov-2-lineage-

418 in-manaus-preliminary-findings/586 (2021). 
medRxiv preprint doi: https://doi.org/10.1101/2021.05.25.21257695; this version posted May 27, 2021. The copyright holder for this preprint (which was not certified by peer review) is the author/funder, who has granted medRxiv a license to display the preprint in perpetuity. It is made available under a CC-BY-NC-ND 4.0 International license .

4196. Hodcroft, E. B. et al. Emergence and spread of a SARS-CoV-2 variant through Europe in the 420 summer of 2020. medRxiv 2020.10.25.20219063 (2021) doi:10.1101/2020.10.25.20219063.

4217. Eurosurveillance | GISAID: Global initiative on sharing all influenza data - from vision to reality.

422 https://www.eurosurveillance.org/content/10.2807/1560-7917.ES.2017.22.13.30494.

4238. Komissarov, A. B. et al. Genomic epidemiology of the early stages of the SARS-CoV-2 outbreak 424 in Russia. Nat. Commun. 12, 649 (2021).

4259. CoVizu. Near real-time visualization of SARS-CoV-2 (hCoV-19) genomic variation

426 https://filogeneti.ca/CoVizu/ (2021).

42710. Kosakovsky Pond, S. L. \& Frost, S. D. W. Not So Different After All: A Comparison of Methods 428 for Detecting Amino Acid Sites Under Selection. Mol. Biol. Evol. 22, 1208-1222 (2005). 42911. Murrell, B. et al. Detecting Individual Sites Subject to Episodic Diversifying Selection. PLOS $430 \quad$ Genet. 8, e1002764 (2012).

43112. Selection history of genes in SARS-CoV-2/COVID-19 genomes enabled by data from. 432 https://observablehq.com/@spond/sc2-genes (2021).

43313. Oliveira, S. C., de Magalhães, M. T. Q. \& Homan, E. J. Immunoinformatic Analysis of SARS434 CoV-2 Nucleocapsid Protein and Identification of COVID-19 Vaccine Targets. Front. Immunol. 435 11, (2020).

43614. Genomics and epidemiology of the P.1 SARS-CoV-2 lineage in Manaus, Brazil | Science. 437 https://science.sciencemag.org/content/early/2021/04/13/science.abh2644. 43815. Dejnirattisai, W. et al. Antibody evasion by the P.1 strain of SARS-CoV-2. Cell (2021) 439 doi:10.1016/i.cell.2021.03.055.

44016. Dejnirattisai, W. et al. The antigenic anatomy of SARS-CoV-2 receptor binding domain. Cell $441 \quad$ 184, 2183-2200.e22 (2021).

44217. Gaebler, C. et al. Evolution of Antibody Immunity to SARS-CoV-2. bioRxiv 2020.11.03.367391 $443 \quad$ (2021) doi:10.1101/2020.11.03.367391.

44418. Liu, Z. et al. Landscape analysis of escape variants identifies SARS-CoV-2 spike mutations that 445 attenuate monoclonal and serum antibody neutralization. bioRxiv 2020.11.06.372037 (2021) $446 \quad$ doi: $10.1101 / 2020.11 .06 .372037$. 
medRxiv preprint doi: https://doi.org/10.1101/2021.05.25.21257695; this version posted May 27, 2021. The copyright holder for this preprint (which was not certified by peer review) is the author/funder, who has granted medRxiv a license to display the preprint in perpetuity.

It is made available under a CC-BY-NC-ND 4.0 International license .

44719. Serine 477 plays a crucial role in the interaction of the SARS-CoV-2 spike protein with the

448 human receptor ACE2 | Scientific Reports. https://www.nature.com/articles/s41598-021-83761-

$449 \underline{5}$.

45020. CoVariants. https://covariants.org/variants/20A.EU2.

45121. A Novel and Expanding SARS-CoV-2 Variant, B.1.526, Identified in New York / medRxiv.

452 https://www.medrxiv.org/content/10.1101/2021.02.23.21252259v2.full.

45322. West, A. P. et al. Detection and characterization of the SARS-CoV-2 lineage B.1.526 in New

454 York. bioRxiv 2021.02.14.431043 (2021) doi:10.1101/2021.02.14.431043.

45523. The expert reported on the mutation of the coronavirus in 13 regions of the Russian Federation

456 (in Russian). https://www.interfax.ru/russia/737621.

45724. Dangerous COVID-19 mutations, which Popova warned about, were found in the Urals (in

$458 \quad$ Russian). vesti.ru https://www.vesti.ru/article/2486564.

45925. Guruprasad, L. Evolutionary relationships and sequence-structure determinants in human

460 SARS coronavirus-2 spike proteins for host receptor recognition. Proteins Struct. Funct.

461 Bioinforma. 88, 1387-1393 (2020).

46226. Cerutti, G. et al. Potent SARS-CoV-2 Neutralizing Antibodies Directed Against Spike N-Terminal

463 Domain Target a Single Supersite. bioRxiv 2021.01.10.426120 (2021)

464 doi:10.1101/2021.01.10.426120.

46527. Chi, X. et al. A neutralizing human antibody binds to the $\mathrm{N}$-terminal domain of the Spike protein

466 of SARS-CoV-2. Science 369, 650-655 (2020).

46728. outbreak.info. outbreak.info https://outbreak.info/.

46829. Cubuk, J. et al. The SARS-CoV-2 nucleocapsid protein is dynamic, disordered, and phase

469 separates with RNA. Nat. Commun. 12, 1936 (2021).

47030. Thornlow, B. et al. A new SARS-CoV-2 lineage that shares mutations with known Variants of

471 Concern is rejected by automated sequence repository quality control. bioRxiv

$472 \quad 2021.04 .05 .438352(2021)$ doi:10.1101/2021.04.05.438352.

47331. Gao, T. et al. Identification and functional analysis of the SARS-COV-2 nucleocapsid protein.

$474 \quad$ BMC Microbiol. 21, 58 (2021). 
medRxiv preprint doi: https://doi.org/10.1101/2021.05.25.21257695; this version posted May 27, 2021. The copyright holder for this preprint (which was not certified by peer review) is the author/funder, who has granted medRxiv a license to display the preprint in perpetuity.

It is made available under a CC-BY-NC-ND 4.0 International license.

47532. The sequence at Spike S1/S2 site enables cleavage by furin and phospho-regulation in SARS-

476 CoV2 but not in SARS-CoV1 or MERS-CoV 1 Scientific Reports.

477 https://www.nature.com/articles/s41598-020-74101-0.

47833. Maison, D. P., Ching, L. L., Shikuma, C. M. \& Nerurkar, V. R. Genetic Characteristics and

479 Phylogeny of 969-bp S Gene Sequence of SARS-CoV-2 from Hawaii Reveals the Worldwide

480 Emerging P681H Mutation. bioRxiv 2021.01.06.425497 (2021) doi:10.1101/2021.01.06.425497.

48134. Voloch, C. M. et al. Genomic characterization of a novel SARS-CoV-2 lineage from Rio de

$482 \quad$ Janeiro, Brazil. medRxiv 2020.12.23.20248598 (2020) doi:10.1101/2020.12.23.20248598.

48335. Identification of SARS-CoV-2 spike mutations that attenuate monoclonal and serum antibody

484 neutralization: Cell Host \& Microbe. https://www.cell.com/cell-host-microbe/fulltext/S1931-

$485 \quad \underline{3128(21) 00044-5 .}$

48636. Andreano, E. et al. SARS-CoV-2 escape in vitro from a highly neutralizing COVID-19

487 convalescent plasma. bioRxiv 2020.12.28.424451 (2020) doi:10.1101/2020.12.28.424451.

48837. Greaney, A. J. et al. Comprehensive mapping of mutations in the SARS-CoV-2 receptor-binding 489 domain that affect recognition by polyclonal human plasma antibodies. Cell Host Microbe $\mathbf{0}$.

$490 \quad \underline{(2021)}$.

49138. McCarthy, K. R. et al. Recurrent deletions in the SARS-CoV-2 spike glycoprotein drive antibody

492 escape. Science 371, 1139-1142 (2021).

49339. The first case of the 'British variant' of the coronavirus is detected in Russia (in Russian).

$494 \quad$ Kommersant https://www.kommersant.ru/doc/4639704 (2021).

49540. Emma Griffiths et al. CanCOGeN Interim Recommendations for Naming, Identifying, and

496 Reporting SARS-CoV-2 Variants of Concern.

49741. CDC. SARS-CoV-2 Variant Classifications and Definitions. Centers for Disease Control and

498 Prevention https://www.cdc.gov/coronavirus/2019-ncov/cases-updates/variant-

499 surveillance/variant-info.html (2021).

50042. Washington, N. L. et al. Genomic epidemiology identifies emergence and rapid transmission of

501 SARS-CoV-2 B.1.1.7 in the United States. medRxiv 2021.02.06.21251159 (2021)

502 doi:10.1101/2021.02.06.21251159. 
medRxiv preprint doi: https://doi.org/10.1101/2021.05.25.21257695; this version posted May 27, 2021. The copyright holder for this preprint (which was not certified by peer review) is the author/funder, who has granted medRxiv a license to display the preprint in perpetuity.

It is made available under a CC-BY-NC-ND 4.0 International license .

50343. Katoh, K. \& Standley, D. M. MAFFT multiple sequence alignment software version 7:

504 improvements in performance and usability. Mol. Biol. Evol. 30, 772-780 (2013).

50544. https://github.com/nextstrain/ncov/blob/master/defaults/exclude.txt. GitHub

506 https://github.com/nextstrain/ncov/blob/master/defaults/exclude.txt.

50745. Matsvay, A. et al. Genomic epidemiology of SARS-CoV-2 in Russia reveals recurring cross-

508 border transmission throughout 2020. medRxiv 2021.03.31.21254115 (2021)

$509 \quad$ doi:10.1101/2021.03.31.21254115.

51046. Harrel, F. E., Jr. \& others, with contributions from C. D. and many. Hmisc: Harrell

511 Miscellaneous. (2021).

51247. Wickham, H. ggplot2: Elegant Graphics for Data Analysis. (Springer-Verlag, 2009).

513 doi:10.1007/978-0-387-98141-3.

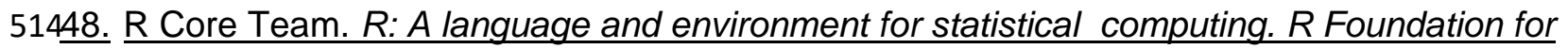

515 Statistical Computing. (2013).

51649. Conway, J. \& Gehlenborg, N. UpSetR: A More Scalable Alternative to Venn and Euler Diagrams

517 for Visualizing Intersecting Sets. (2019).

51850. Baty, F. et al. A Toolbox for Nonlinear Regression in R: The Package nlstools. J. Stat. Softw.

$519 \quad 66,1-21(2015)$.

52051. Wickham, H. et al. Welcome to the Tidyverse. J. Open Source Softw. 4, 1686 (2019).

52152. Auguie, B. \& Antonov, A. gridExtra: Miscellaneous Functions for 'Grid' Graphics. (2017).

52253. Stamatakis, A. RAxML-VI-HPC: maximum likelihood-based phylogenetic analyses with

523 thousands of taxa and mixed models. Bioinformatics 22, 2688-2690 (2006).

52454. schrodinger/pymol-open-source. (Schrödinger, Inc., 2021).

52555. Multiplexed RT-qPCR to screen for SARS-COV-2 B.1.1.7 variants: Preliminary results - SARS-

526 CoV-2 coronavirus / nCoV-2019 Diagnostics and Vaccines. Virological

527 https://virological.org/t/multiplexed-rt-qpcr-to-screen-for-sars-cov-2-b-1-1-7-variants-preliminary-

528 results $/ 588(2021)$.

52956. Takada, K., Ueda, M. T., Watanabe, T. \& Nakagawa, S. Genomic diversity of SARS-CoV-2 can

530 be accelerated by a mutation in the nsp14 gene. bioRxiv 2020.12.23.424231 (2020)

531 doi:10.1101/2020.12.23.424231. 
medRxiv preprint doi: https://doi.org/10.1101/2021.05.25.21257695; this version posted May 27, 2021. The copyright holder for this preprint (which was not certified by peer review) is the author/funder, who has granted medRxiv a license to display the preprint in perpetuity. It is made available under a CC-BY-NC-ND 4.0 International license.

53257. Variants: distribution of cases data. GOV.UK https://www.gov.uk/government/publications/covid-

533 19-variants-genomically-confirmed-case-numbers/variants-distribution-of-cases-data.

53458. Preliminary genomic characterisation of an emergent SARS-CoV-2 lineage in the UK defined by 535 a novel set of spike mutations - SARS-CoV-2 coronavirus / nCoV-2019 Genomic Epidemiology.

536 Virological https://virological.org/t/preliminary-genomic-characterisation-of-an-emergent-sars-

537 cov-2-lineage-in-the-uk-defined-by-a-novel-set-of-spike-mutations/563 (2020).

538

539 Supplementary Information 
medRxiv preprint doi: https://doi.org/10.1101/2021.05.25.21257695; this version posted May 27, 2021. The copyright holder for this preprint (which was not certified by peer review) is the author/funder, who has granted medRxiv a license to display the preprint in perpetuity.

It is made available under a CC-BY-NC-ND 4.0 International license.




medRxiv preprint doi: https://doi.org/10.1101/2021.05.25.21257695; this version posted May 27, 2021. The copyright holder for this preprint (which was not certified by peer review) is the author/funder, who has granted medRxiv a license to display the preprint in perpetuity.

It is made available under a CC-BY-NC-ND 4.0 International license .

541 Fig. S1. Frequency dynamics of SARS-CoV-2 amino acid changes in different regions of 542 Russia. Notations are the same as in Fig.2.

543
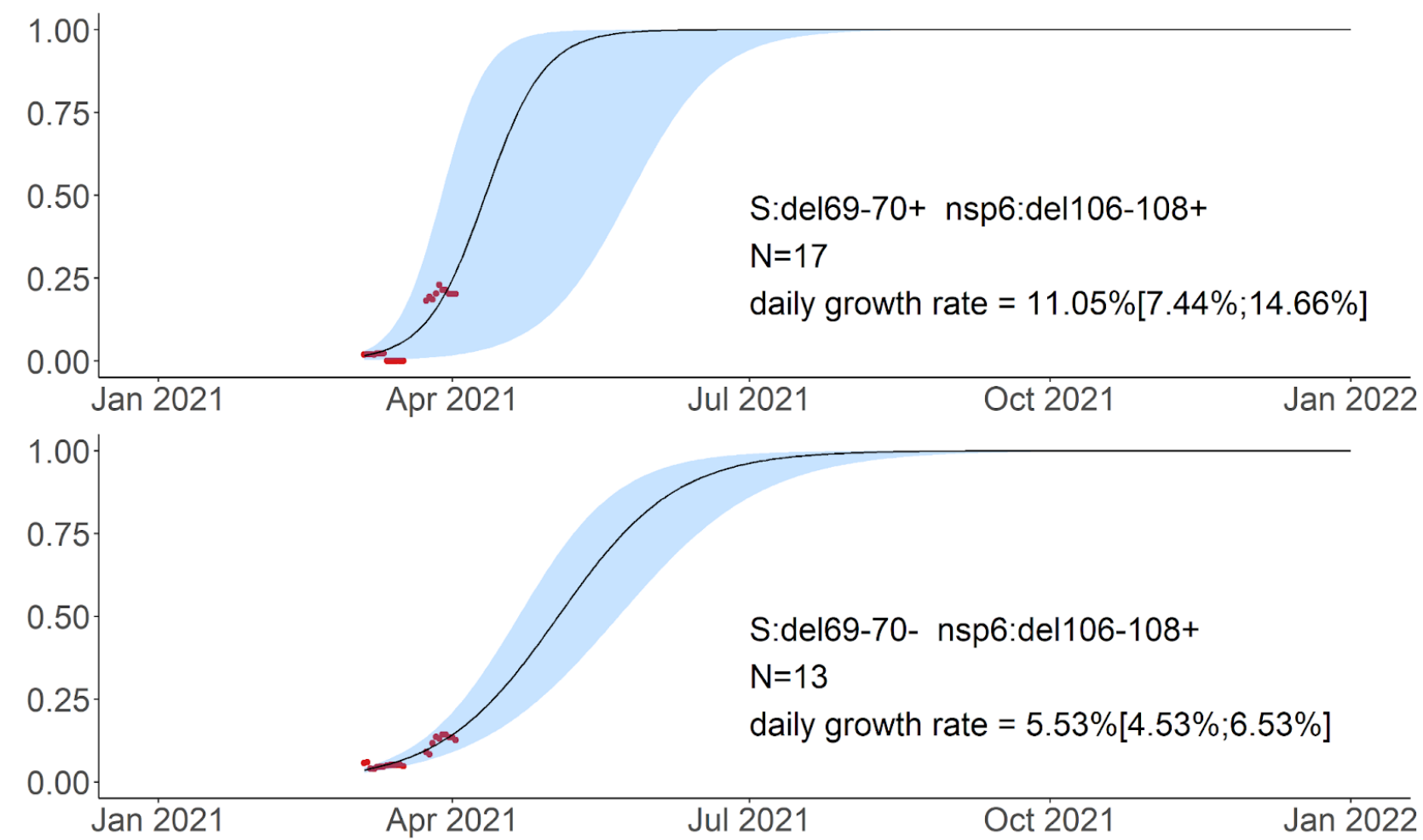

545 Fig. S2. Logistic growth model for the S: $\Delta 69-70+$ nsp6: $\Delta 106-108+$ and S: $\Delta 69-70$. nsp6: $\Delta 106-108+$ samples in Feb-Apr 2021 based on the 136 samples for which no NGS data was available. Notations are the same as in Fig. 6. 
medRxiv preprint doi: https://doi.org/10.1101/2021.05.25.21257695; this version posted May 27, 2021. The copyright holder for this preprint (which was not certified by peer review) is the author/funder, who has granted medRxiv a license to display the preprint in perpetuity.

It is made available under a CC-BY-NC-ND 4.0 International license.
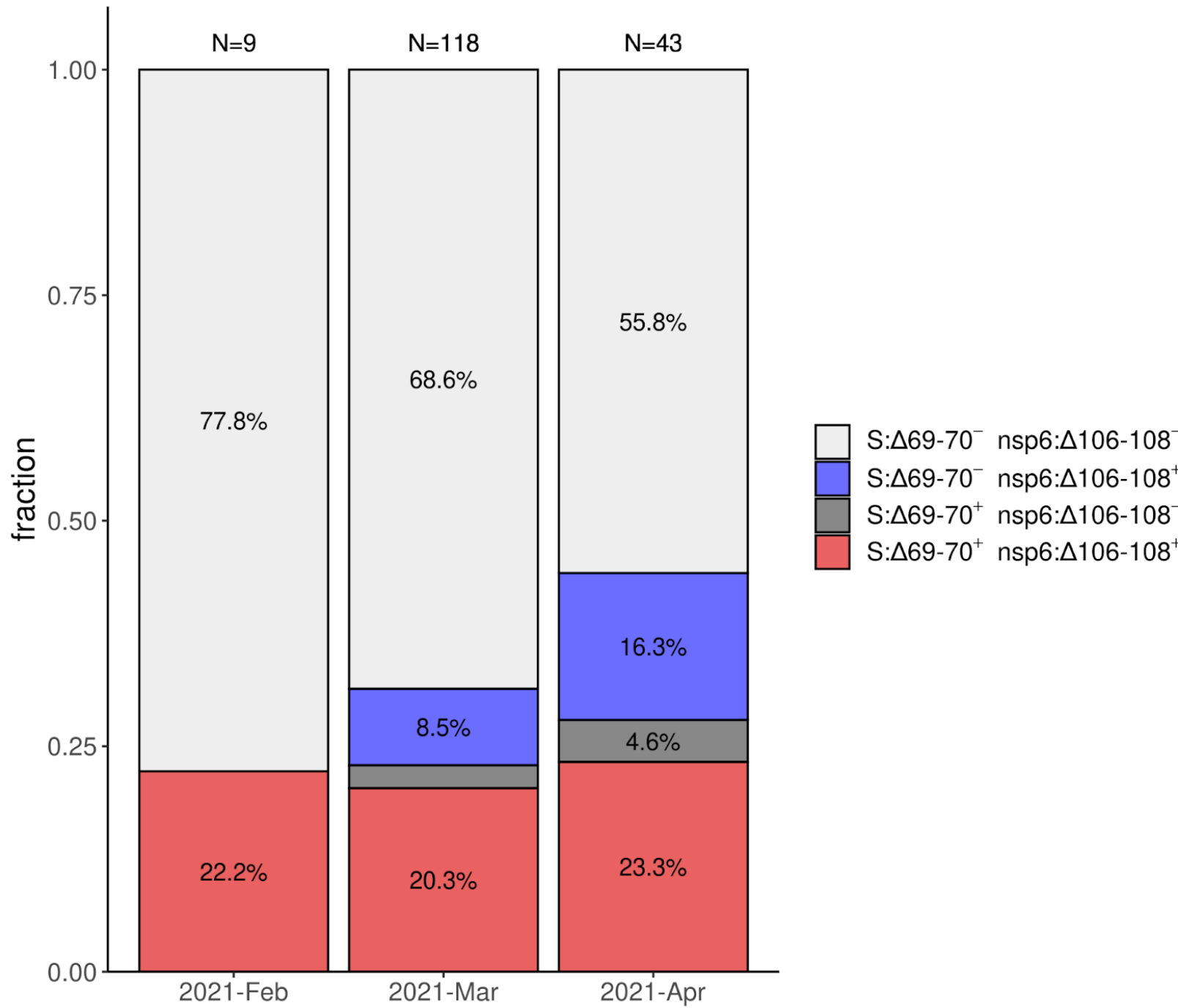

550 Figure S3. Frequencies of S: $\Delta 69-70$, nsp6: $\Delta 106-108$, and their combination in Saint 551 Petersburg in Feb-Apr 2021 based on the PCR data. 
medRxiv preprint doi: https://doi.org/10.1101/2021.05.25.21257695; this version posted May 27, 2021. The copyright holder for this preprint (which was not certified by peer review) is the author/funder, who has granted medRxiv a license to display the preprint in perpetuity. It is made available under a CC-BY-NC-ND 4.0 International license .
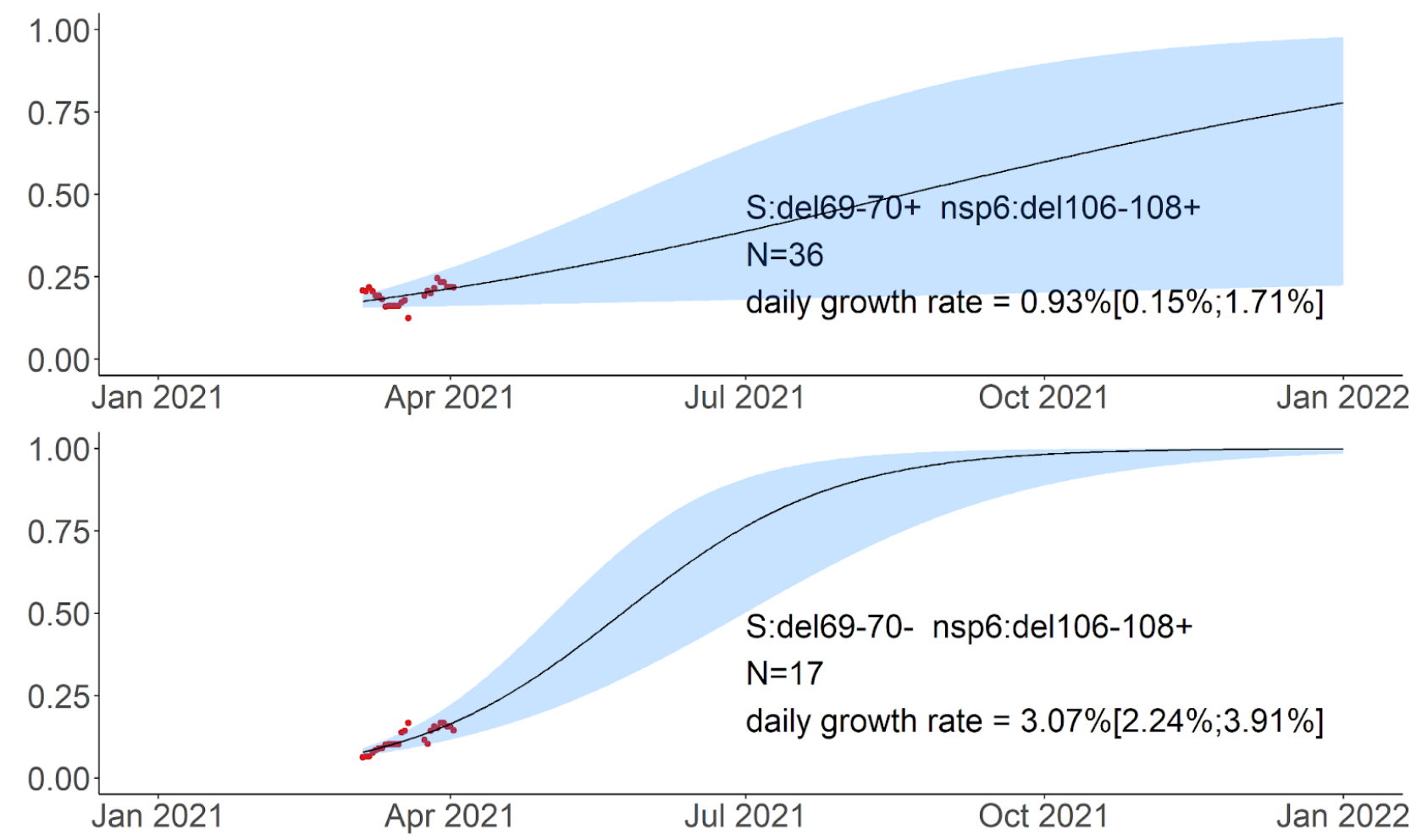

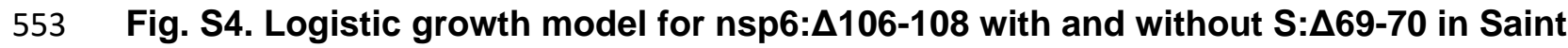
554 Petersburg in Feb-Apr 2021 based on PCR data. Notations are the same as in Fig. 5. 